\title{
Climate and vegetation dynamics of the northern Apennines (Italy) during the late Pleistocene and Holocene
}

\section{Article}

Accepted Version

Creative Commons: Attribution-Noncommercial-No Derivative Works 4.0

Guido, M. A., Molinari, C., Moneta, V., Branch, N., Black, S., Simmonds, M., Stastney, P. and Montanari, C. (2020) Climate and vegetation dynamics of the northern Apennines (Italy) during the late Pleistocene and Holocene. Quaternary Science Reviews, 231 (1). 106206. ISSN 0277-3791 doi:

https://doi.org/10.1016/j.quascirev.2020.106206 Available at https://centaur.reading.ac.uk/88896/

It is advisable to refer to the publisher's version if you intend to cite from the work. See Guidance on citing.

To link to this article DOI: http://dx.doi.org/10.1016/j.quascirev.2020.106206

Publisher: Elsevier

All outputs in CentAUR are protected by Intellectual Property Rights law, including copyright law. Copyright and IPR is retained by the creators or other copyright holders. Terms and conditions for use of this material are defined in the End User Agreement. 


\section{CentAUR}

Central Archive at the University of Reading

Reading's research outputs online 
1 Climate and Vegetation Dynamics of the Northern Apennines (Italy) during the Late

2 Pleistocene and Holocene

4 Maria Angela Guido ${ }^{\mathrm{a}}$, Chiara Molinari ${ }^{\mathrm{b}}$, Valentina Moneta ${ }^{\mathrm{a}}$, Nicholas Branch $^{\mathrm{c}}$, Stuart Black ${ }^{\mathrm{c}}$,

$5 \quad$ Michael Simmonds ${ }^{\mathrm{c}}$, Philip Stastney ${ }^{\mathrm{d}}$, Carlo Montanari ${ }^{{ }^{*}}$

$6 \quad{ }^{a}$ Department of Earth, Environment and Life Sciences (DISTAV), University of Genova, Corso

7 Europa 26, 16132, Genoa, Italy

$8 \quad$ b Department of Physical Geography and Ecosystem Science, Lund University, Sölvegatan 12, S-

9223 62, Lund, Sweden

* Corresponding author: Carlo Montanari (carlo.montanari@unige.it). Department of Earth, Environment and Life Sciences (DISTAV), University of Genova, Corso Europa 26, 16132, Genoa, Italy

Other Authors' email: M.A.Guido (Maria.Angela.Guido@unige.it); C.Molinari (chiara.molinari@nateko.lu.se); V.Moneta (monetavalentina@virgilio.it); N.Branch (n.p.branch@ reading.ac.uk); S.Black (s.black@ reading.ac.uk); M.Simmonds (m.j.simmonds@ reading.ac.uk); P. Stastney (pstastney@ mola.org.uk)

\section{Abstract}

This study reconstructs the regional vegetation and climate dynamics between the upper Late Pleistocene and Holocene around Pian del Lago, a coastal mountain marshland located at $831 \mathrm{~m}$ asl in western Liguria (NW-Italy), based on the pollen analysis of a $13 \mathrm{~m}$-long sediment core. The record provided a unique opportunity to study a poorly documented period in northern Italy and across many parts of southwestern Europe. We propose an event stratigraphy based upon the identification of seven interstadials (NAI-7 to NAI-1) spanning the upper Late Pleistocene. The correlation with other terrestrial records in Italy, and with Mediterranean marine sequences and the 
Greenland ice cores, permitted a coherent reconstruction of main environmental changes from $>\sim 43,000$ cal. BP. Significantly, the pollen record indicates the persistence of a mesophilous mountain vegetation cover, mainly composed of Quercus (deciduous and evergreen), Abies, Fagus and Alnus over the whole time period recorded. At the Last Glacial Maximum (LGM) and during the Late Würm Lateglacial, despite the presence of steppic vegetation composed of Artemisia, woodlands dominated by Pinus, with Abies, Picea, Fagus, Alnus and Betula are present. This forest composition provides an important insight into the history of Picea in southern Europe and Late Pleistocene refugia for mesophilous species. During the Early Holocene, Pinus is first replaced by Abies and then by deciduous Quercus and mixed temperate species as the dominant forest component. Both arboreal and herbaceous anthropogenic pollen indicators only make their appearance during the Late Holocene, attesting to the increasing importance of human activities .

\section{Keywords}

North-western Italy, Late Pleistocene, Holocene, Pollen Analysis, Micro-charcoal Analysis

\section{Introduction}

During the last few decades, several palynological studies have documented the Holocene environmental dynamics of the northern Apennines, NW Italy (e.g. Bellini et al., 2009a; Bertoldi et al., 2007; Branch, 2004, 2013; Branch and Marini, 2013; Branch and Morandi, 2015; Branch et al., 2014; Cruise, 1990a, 1990b; Cruise and Maggi, 2000; Cruise et al., 2009; Guido et al., 2003, 2004a, 2009, 2013; Lowe, 1992; Maggi, 2000; Morandi and Branch, 2018; Watson, 1996), including coastal areas (Arobba et al., 2018; Bellini et al., 2009b; Guido et al., 2004b, 2004c; Mariotti Lippi et al., 2004; 2007; Montanari et al., 1998; Montanari et al., 2014; Piccazzo et al., 1994). Very little is known about the upper Late Pleistocene $(\sim 50,000-11,700$ cal. BP), however, with the majority of records only covering the Late Würm Lateglacial ( 14,800-11,700 cal. BP), (e.g. Branch 2004; Branch and Morandi, 2015; Lowe, 1992; Lowe and Watson, 1993; Vescovi et al., 2010a, 2010b; 
Watson, 1996). The only sites with a chronology covering the whole period in NW Italy are Lago di Massaciuccoli (Menozzi et al., 2002), Berceto (Bertoldi et al., 2007) and Ivrea (Arobba et al., 1997; Gianotti et al., 2008; 2015). Additional information for this time frame has been obtained from archaeological studies (mainly coastal caves), but these sedimentary archives are generally unsuitable for regional palaeoenvironmental reconstructions (see Kaniewski et al., 2005) (Fig. 1).

3

4

5

66

67

8

9

70

This new study from Pian del Lago provided a unique opportunity to fill this chrono-stratigraphic gap for NW Italy (cf. Magri, 2010; Magri et al., 2015) enabling: (1) reconstruction of the main vegetation dynamics of the area during the upper Late Pleistocene and the Holocene ( 43,000-8000 cal. BP); (2) significantly improved understanding of the response of the northern Apennines to known periods of abrupt climate change towards the end of the last glaciation; (3) greater appreciation of the environmental and climatic setting for major developments in the human history of southwestern Europe and the Mediterranean.

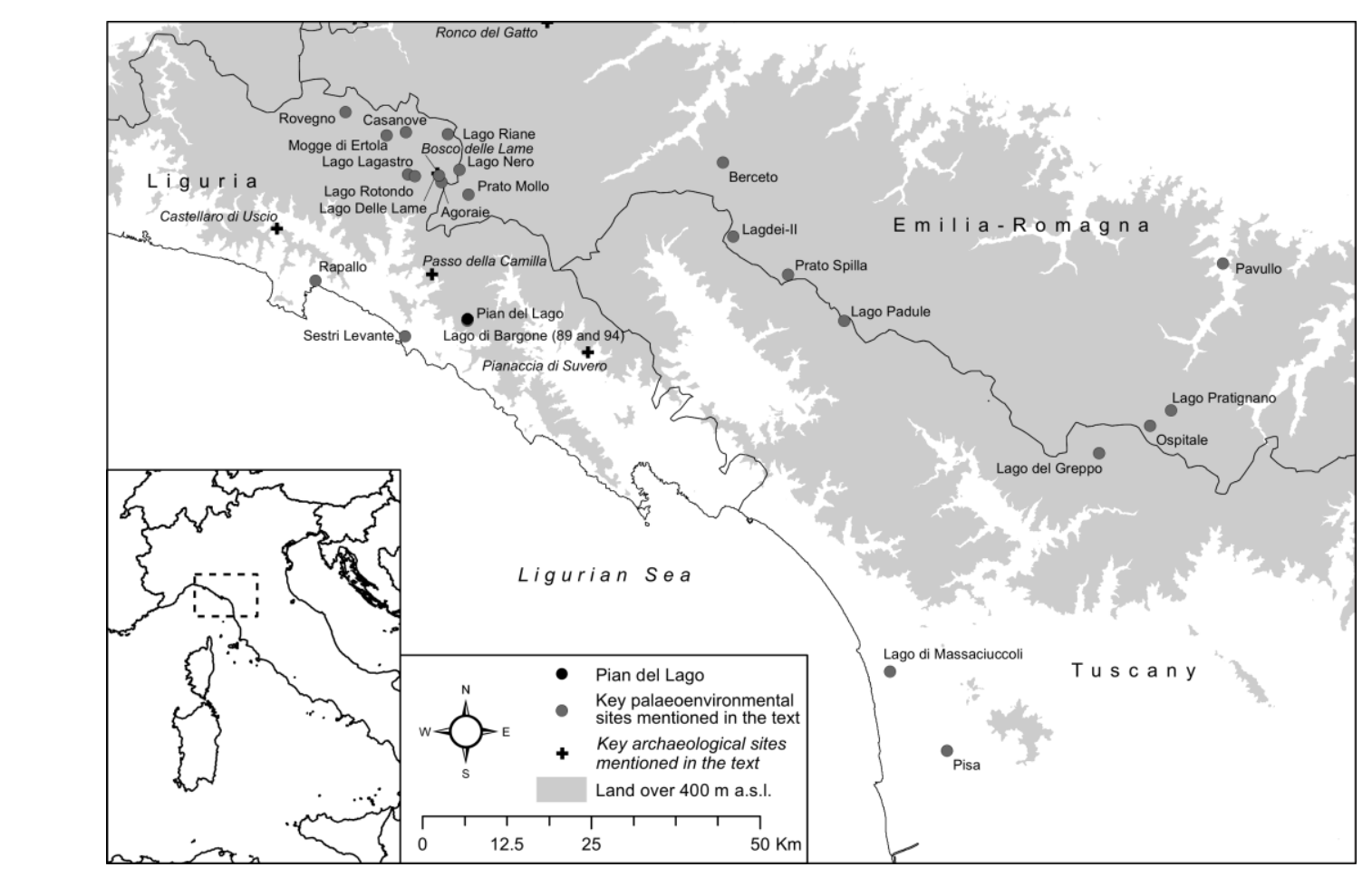

Fig. 1: Location of Pian del Lago and key Late Pleistocene and Holocene palaeoenvironmental records from the northern Apennines mentioned in the text 


\section{Geographical and environmental setting}

Pian del Lago is located near the village of Bargone, Casarza Ligure (Genova), Western Liguria, north-western Italy, at around $830 \mathrm{~m}$ a.s.1. and less than $3 \mathrm{~km}$ away from the coast (Fig.1 and Fig.2). The watershed ridge, marking the boundary of the catchment, reaches fairly high altitudes, considering the proximity of the sea: M. Roccagrande $(971 \mathrm{~m})$ and M. Tregin $(870 \mathrm{~m})$ on the western side, M. Alpe (1093 m), M. Zenone (1055 m) and M. Pu (1001 m) on the eastern side. These mountains are mainly of ophiolitic nature, but there are also sediments (e.g. jasper with manganese) that covered the submarine effusions. This explains the presence, since prehistoric times, of copper, iron and manganese mines in the surrounding area.

The climate of the area is sub-Mediterranean. Data from Castiglione Chiavarese weather station (300 $\mathrm{m}$ a.s.1.) indicate a mean annual temperature of $13^{\circ}-14^{\circ} \mathrm{C}$, with a maximum in summer (mean above $\left.22^{\circ} \mathrm{C}\right)$ and a minimum in winter $\left(6-8{ }^{\circ} \mathrm{C}\right)$. The mean annual precipitation is $1300 \mathrm{~mm}$, while the average monthly rainfall distribution shows a maximum in November $(160 \mathrm{~mm})$ and a minimum in July (less than $50 \mathrm{~mm}$ ). Before specific palaeoenvironmental studies were made, the origin of the swamp was attributed to periglacial phenomena, which would be consistent with other northern Apennines wetlands (cf. Cruise, 1990a). Faccini et al. (2009) have instead recognized deep-seated gravitational slope deformations (DSGSD), which is a geomorphological feature characterising other Ligurian landscapes. The palaeoenvironmental research presented here confirms that this phenomenon is older than $\sim 43,000$ years.

The wetland contains lacustrine sediments, with thickness varying from a few metres to about 13.30 $\mathrm{m}$. Despite to the altitude and proximity to the coast that cause a relatively mild humid climate, this is a mountain site comparable to other upland wetlands studied by pollen analysis in the massif of M. Beigua, western Ligurian coast (Guido et al., 2004a). The area surrounding the plateau is mainly treeless, except for the local reforestation with Pinus nigra. At slightly lower elevations meso- 
thermophilic deciduous forests of Quercus cerris L. (Turkey-oak), Q. pubescens Willd. (white oak),

112 Q. ilex L. (holm oak), Ostrya carpinifolia Scop. (hop-hornbeam) and abandoned orchards of 113 Castanea sativa Miller (sweet chestnut) are widespread. Presently, the area is included in the 114 European ecological network Natura 2000, designed to protect the most endangered habitats and 115 species, and it belongs to the Site of Community Interest (SIC IT1342806 M. Verruga - M. Zenone $116-$ M. Roccagrande - M. Pu).

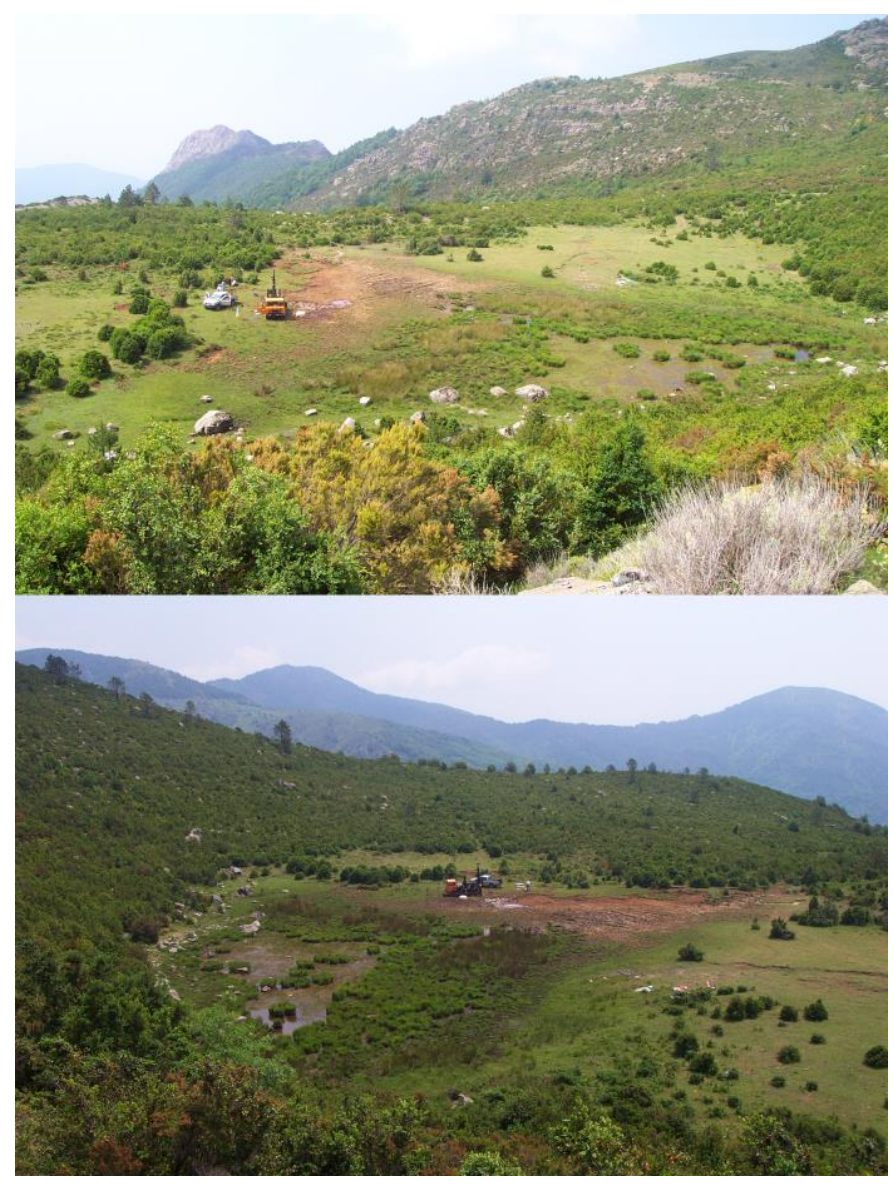

Fig. 2: Photographs of Pian del Lago during the field investigations (top - west facing; bottom - east facing) (in color online)

The plateau hosting the small wetland is partially occupied by grassland, formerly a pastureland, which is more and more invaded by a post-cultural scrubland dominated by Buxus sempervirens L. and heathland with Calluna vulgaris (L.) Hull, Erica carnea L., E. arborea L., Pteridium aquilinum (L.) Kuhn etc. The mire includes hygro-hydrophilous vegetation, i.e. sedges populations (Carex cfr. caespitosa L., C. distans L., C. flava L., C. pallescens L., C. panicea L., C. stellulata Good., C. 
tumidicarpa Anderss.), stands of bulrushes (Juncus articulatus L., J. effusus L., J. fontanesii J. Gay, J. tenageja Ehrh.), Typha latifolia L. and Molinia caerulea (L.) Moench (Fig. 2).

\section{Field and laboratory methods}

One of the several cores sampled during the field campaign was studied for bio-stratigraphical analyses. This core (S1) is $1330 \mathrm{~cm}$ long and $10 \mathrm{~cm}$ in diameter and was recovered using a rotary drilling rig. Sub-samples for pollen and microcharcoal analysis were extracted every 5 or $10 \mathrm{~cm}$, although sub-sampling was occasionally impossible due to the presence of stones or coarse sediment. In total, 100 levels have provided statistically valid pollen counts. Approximately $2 \mathrm{~cm}^{3}$ of sediment were processed according to standard palynological treatments (Moore et al., 1991). With only some exceptions, a minimum of 300 pollen grains were counted (aquatic and spore taxa were excluded from the pollen sum). Pollen identification was completed to the lowest taxonomic level possible using reference materials and pollen atlases held at the University of Genoa (Punt, 1976; Punt and Blackmore, 1991; Punt and Clarke, 1980, 1981, 1984; Punt et al., 1988, 1995; Reille, 1992-1998). Pollen percentages and microcharcoal influx (particles $\mathrm{cm}^{-2} \mathrm{yr}^{-1}$ ) were calculated, and the results plotted using TILIA and TILIA.GRAPH version 2.1.1 (Grimm, 1993). Local pollen-assemblage zones (LPAZs) were identified using stratigraphically constrained cluster analysis (Grimm, 1987).

Chronological control for the sequence was provided by a Bayesian age-depth model based on 10 conventional AMS ${ }^{14} \mathrm{C}$ dating (Stuiver and Polach, 1977) and on 3 Uranium series dates (Table 1). The AMS ${ }^{14} \mathrm{C}$ samples were dated at CEDAD, University of Salento (Italy). All radiocarbon samples were prepared using standard acid-alkali-acid pre-treatment and were quoted in accordance with international standards (Stuiver and Kra, 1986). The radiocarbon ages were calibrated to the calendar timescale and a Bayesian age-depth model was generated using the $\mathrm{R}$ package (R Core Team, 2016) Bacon v.2.3.4 (Blaauw and Christen, 2011) and the IntCal13 radiocarbon calibration 


\begin{tabular}{|c|c|c|c|c|c|c|}
\hline $\begin{array}{l}\text { Lab code } \\
\text { (dates } \\
\text { marked* } \\
\text { excluded } \\
\text { from age } \\
\text { model) }\end{array}$ & Depth (cm) & Material & $\delta 13 C(\% \circ)$ & ${ }^{14} \mathrm{C}$ age (BP) & $\begin{array}{l}\text { U/Th age } \\
\text { (BP) }\end{array}$ & $\begin{array}{l}\text { Calibrated } \\
\text { age range } \\
\text { cal BP } \\
(95.4 \% \\
\text { confidence) }\end{array}$ \\
\hline LTL3092A & 100 & Clay & -27.0 & $534 \pm 45$ & & $650-500$ \\
\hline LTL4200A & 180 & Peat & -27.5 & $3483 \pm 50$ & & $3890-3630$ \\
\hline LTL4201A & 290 & Peat & -25.3 & $8892 \pm 60$ & & $10,200-9770$ \\
\hline LTL4202A & 380 & Silty clay & -28.1 & $9625 \pm 75$ & & $\begin{array}{l}11,200- \\
10,740\end{array}$ \\
\hline U-series1 & 400 & Diatomite & & & $13,840 \pm 750$ & $\begin{array}{l}14,220- \\
13,200\end{array}$ \\
\hline U-series2 & 432 & Diatomite & & & $21,260 \pm 320$ & $\begin{array}{l}21,580- \\
20,930\end{array}$ \\
\hline U-series3 & 464 & Diatomite & & & $21,550 \pm 370$ & $\begin{array}{l}21,920- \\
21,170\end{array}$ \\
\hline LTL12573A & 471 & Clay & -29.0 & $29,917 \pm 150$ & & $\begin{array}{l}34,310- \\
33,710\end{array}$ \\
\hline *LTL4365A & 529 & Clay & -27.1 & $32,755 \pm 300$ & & $\begin{array}{l}37,900- \\
36,060\end{array}$ \\
\hline *LTL4203B & 530 & Clay & -26.5 & $33,081 \pm 280$ & & $\begin{array}{l}38,220- \\
36,420\end{array}$ \\
\hline *LTL4203A & 530 & Clay & -26.3 & $34,214 \pm 500$ & & $\begin{array}{l}40,000- \\
37,320\end{array}$ \\
\hline LTL4204A & 730 & Sandy clay & -30.1 & $29,687 \pm 170$ & & $\begin{array}{l}35,430- \\
34,860\end{array}$ \\
\hline LTL3093A & 960 & Clay & -32.0 & $31,122 \pm 300$ & & $\begin{array}{l}36,030- \\
34,760\end{array}$ \\
\hline LTL12574A & 1110 & Clay & -29.9 & $31,458 \pm 200$ & & $\begin{array}{l}35,840- \\
34,860\end{array}$ \\
\hline LTL1536A & 1281 & Peat & -35.5 & $40,844 \pm 650$ & & $\begin{array}{l}45,560- \\
43,240\end{array}$ \\
\hline
\end{tabular}

curve (Reimer et al., 2013). The Bacon software package creates flexible age-depth models utilising an autoregressive gamma process and is typically robust to the presence of outlying dates since these are modelled using a student-t distribution with wide tails (Christen and Pérez, 2009). 95\% confidence intervals and weighted mean age estimates at $1 \mathrm{~cm}$ intervals along the core were generated through several million Markov chain Monte Carlo iterations (Blaauw and Christen, 2011). 
U-Series dating of amorphous opal silica is well established (Ivanovich and Harmon 1992; Neymark and Paces, 2000; Neymark et al., 2000, 2002). For minerals precipitated from aqueous solutions, U-series dating can provide precise chronologies if samples have high U/Th ratios and have remained closed to post-depositional mobility of U-series nuclides (e.g., Ludwig and Paces, 2002; Neymark and Paces, 2013). Three samples from diatom-rich units were analysed by XRD to quantify the mineralogy prior to age determinations (Sprynskyy et al., 2010; Table 2). Most of the samples are composed of amorphous opal silica (27-67\%) and quartz (17-42\%) with vermiculite, nimite and clinochrysotile, which are the weathering products of iron-rich, nickel-rich and hydrous phases from Serpentinite bedrock, respectively making up the remainder. As a result of the composition, the sub-samples were separated by density with fractions $<2.1 \mathrm{~g} / \mathrm{cm}^{3},<2.3 \mathrm{~g} / \mathrm{cm}^{3}$ and a heavy fraction $>2.8 \mathrm{~g} / \mathrm{cm}^{3}$ together with a whole sample to create isochrons from the subfractions for analysis by mass spectrometry and gamma spectroscopy. For the gamma spectroscopy, samples and fractions were counted on a Harwell Instruments, Broad Energy BE5030 high purity germanium coaxial photon detector at the University of Reading (UK). External reproducibility was checked using international standards (Yokoyama and Nguyen, 1980). For the mass spectrometry, multiple, small sub-samples (100-500 mg) were extracted from the diatom-rich units and subfractions for determination of the ${ }^{234} \mathrm{U} /{ }^{238} \mathrm{U},{ }^{235} \mathrm{U} /{ }^{238} \mathrm{U}$ and ${ }^{230} \mathrm{Th} /{ }^{232} \mathrm{Th}$ ratios by means of a Thermofisher iCAPQ Inductively Coupled Plasma Mass Spectrometer. External reproducibility was checked using international standards (NIST SRM 3164, 4355 and 4357) and by monitoring the (235/238) ratios in the samples to be within the naturally abundant ratio (137.5). U/Th concentrations were also determined via mass spectrometry using the same instrument. Age determinations were calculating following the methodology of Ludwig and Paces (2002). Isochrons were constructed for samples to check the integrity of the ages and correlated errors were reduced by calculating isochron ages in Isoplot v4.15 (Ludwig, 2008) and IsoplotR (Vermeesch, 2018). 


\begin{tabular}{|l|c|c|c|c|c|c|c|}
\hline & Diatomite & \multicolumn{3}{|c|}{ Sediment fraction } & \multicolumn{3}{c|}{ Serpentinite alteration products } \\
\hline $\begin{array}{l}\text { Sample Depth } \\
\text { (cm) }\end{array}$ & $\begin{array}{c}\text { Diatomite } \\
\text { (opal silica) }\end{array}$ & Quartz & Albite (low) & Muscovite & Vermiculite & Clinochrysotile & Nimite \\
\hline $400-401$ & 26.8 & 42.0 & 4.3 & 1.3 & 16.5 & 5.4 & 3.7 \\
\hline $432-433$ & 56.7 & 23.0 & 2.1 & 1.0 & 10.8 & 3.7 & 2.7 \\
\hline $464-465$ & 67.0 & 16.9 & 1.8 & 0.9 & 8.8 & 2.8 & 2.0 \\
\hline
\end{tabular}

188

189 190

191

192

193 194 195 196

Table 2: Proportions (\%) of minerals present in samples analysed for U-Series dating

\section{Results}

\subsection{Sedimentary History and Geochronology}

The results of the U-series and $\mathrm{AMS}{ }^{14} \mathrm{C}$ dating are provided in Table 1 . Although the age modelling approach utilised by the Bacon package is generally robust to the presence of outlying dates, it was not possible to obtain a stable age model that acceptably fitted all the dates. This was taken to indicate the presence of spurious dates in the sequence probably due to the re-deposition of older organics within the basin given the lithological evidence for erosion events in parts of the record (i.e. ingress of coarse sediments and boulders into the basin). LTL4365A, LTL4203A and LTL4203B, which were identified as potential outliers by initial models, were therefore considered to be erroneously old and excluded from subsequent analysis. The resulting age depth plot is presented in Fig. 3.

(1)


The age model indicates a highly variable accumulation rate at Pian del Lago over the past 40,000 years, ranging from less than $10 \mathrm{yr} \mathrm{cm}^{-1}$ (during $\sim 36,580-33,850 \mathrm{cal}$. BP at $1099-750 \mathrm{~cm}$ ) to over $180 \mathrm{yr} \mathrm{cm}^{-1}$ (during $\sim 21,670-12,490 \mathrm{cal}$. BP at 449-400 cm), with a mean accumulation rate of $\sim 36$ $\mathrm{yr} \mathrm{cm}^{-1}$. The average $95 \%$ confidence level was 3300 years, but uncertainties vary considerably throughout the sequence, ranging from only 218 years at the top of the sequence, to a maximum of 7671 years at $600 \mathrm{~cm}$.

A simplified lithostratigraphy for Pian del Lago (core S1) is presented in Table 3. A predominately organic silt/clay with gravel (> 43,490 cal. BP) is overlain by clay and sandy clay deposition from $>\sim 43,490$ to $\sim 34,790$ cal. BP. This was followed by the erosion and deposition of Serpentinite and then gravel $(\sim 34,790$ to $\sim 34,020$ cal. BP), indicating significant destabilisation of slopes surrounding the basin. A further period of Serpentinite deposition occurs from $\sim 30,750-26,880$ cal. BP overlying a unit of sandy clay $(\sim 34,020-30,750$ cal. BP). Thereafter, mineral rich fine-grained sediments are deposited from $\sim 26,880$ to $\sim 9970$ cal. BP (clay and silt), interrupted only by the formation of diatomite between $\sim 21,850-14,360$ cal. BP. Diatomite formation at Pian del Lago may be attributed to successive algal blooms associated with the influx of freshwater into the basin, possibly enriched with minerals due to weathering of surrounding rocks. Although clay and silt deposition persisted into the Early Holocene, suggesting the presence of an unstable land surface surrounding the basin, from $\sim 9970$ to 3205 cal. BP peat formation occurred, indicating increased organic sedimentation and improved stability. From 3205 cal. BP to the present day renewed clay deposition may be strongly associated with a reduction in woodland cover and human impact on the 234 local environment. 


\begin{tabular}{|l|l|l|}
\hline Depth (cm) & Lithostratigraphy (Unit) & $\begin{array}{l}\text { Modelled Age Range (cal. } \\
\text { BP) }\end{array}$ \\
\hline $170-0$ & Clay & $\sim 3205-<565$ \\
\hline $290-170$ & Peat & $\sim 9970-3205$ \\
\hline $320-290$ & Silt & $\sim 10,640-9970$ \\
\hline $410-320$ & Silty clay & $\sim 14,360-10,640$ \\
\hline $450-410$ & Diatomite & $\sim 21,850-14,360$ \\
\hline $580-450$ & Clay & $\sim 26,880-21,850$ \\
\hline $660-580$ & Serpentinite rock & $\sim 30,750-26,880$ \\
\hline $770-660$ & Sandy clay & $\sim 34,020-30,750$ \\
\hline $800-770$ & Gravel & $\sim 34,260-34,020$ \\
\hline $870-800$ & Serpentinite rock & $\sim 34,790-34,260$ \\
\hline $890-870$ & Sandy clay & $\sim 34,940-34,790$ \\
\hline $1040-890$ & Clay & $\sim 36,090-34,940$ \\
\hline $1110-1040$ & Missing & $\sim 36,715-36,090$ \\
\hline $1290-1110$ & Clay & $>\sim 43,490-36,715$ \\
\hline $1350-1290$ & Organic (peat) silt, clay and gravel & $>\sim 43,490$ \\
\hline
\end{tabular}

Table 3: Simplified lithostratigraphy for Pian del Lago (core S1)

\subsection{Vegetation History}

During LPAZ PdL-1a (> 43,400 cal. BP; 1330-1290 cm), woodlands are dominated by Abies (17\%) and Fagus (13.5\%) (Fig. 4a,b,c,d). These were succeeded by Pinus (11\%) and deciduous

Quercus (25\%) (Figure 4). Through the zone Quercus ilex (2.4\%), Alnus (2.3\%), Carpinus (1.9\%), values $\left(\sim 1500\right.$ fragments $\left.\mathrm{cm}^{-2} \mathrm{yr}^{-1}\right)$ are not very high compared to the long-term mean, suggesting that during this period fire is not a very important disturbance factor.
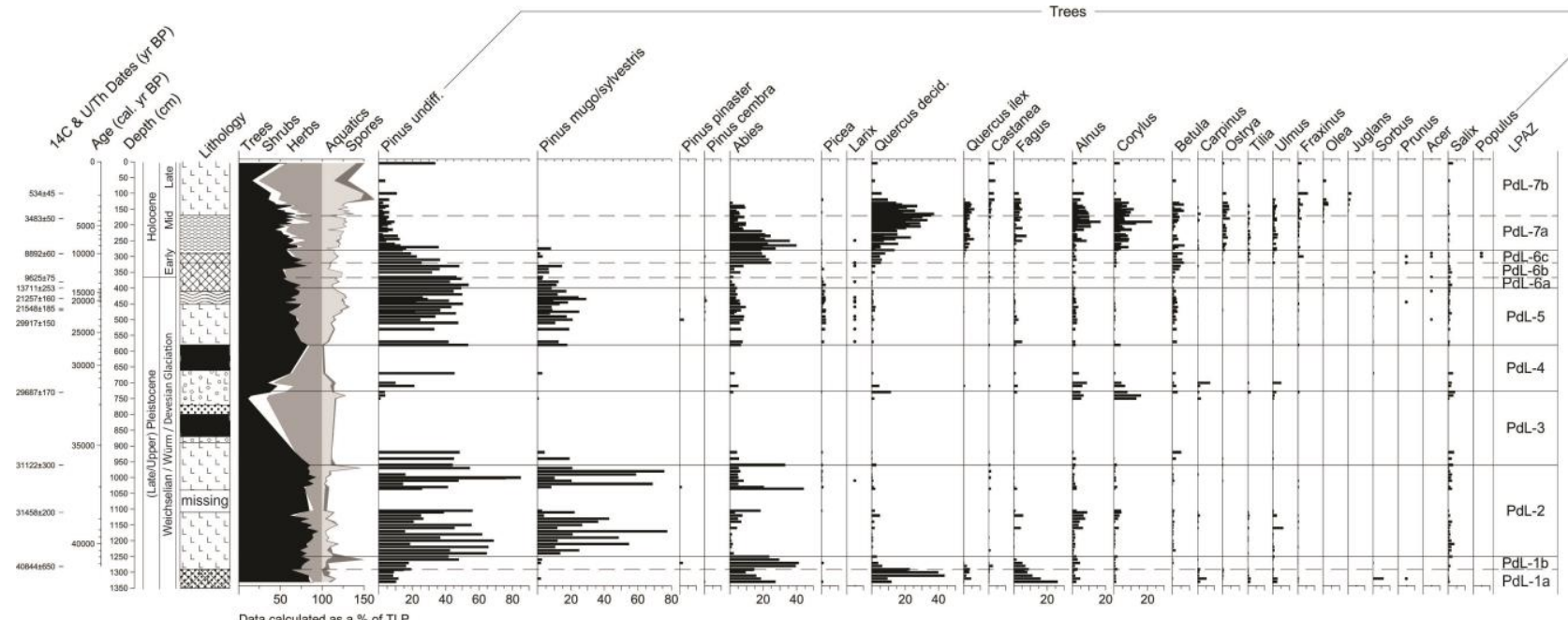


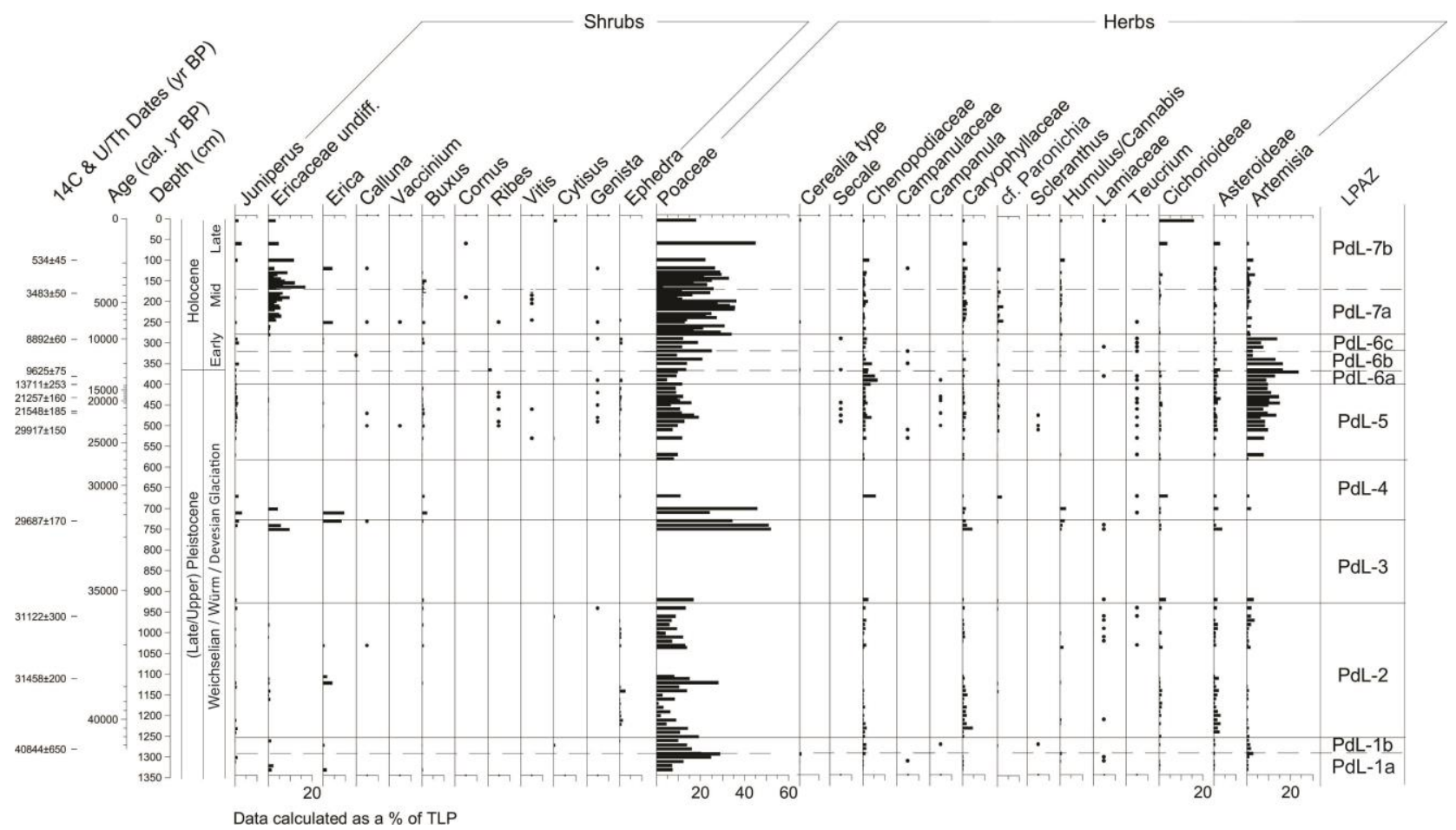

Fig. 4b. Pollen diagram from Pian del Lago: shrubs and herbs 


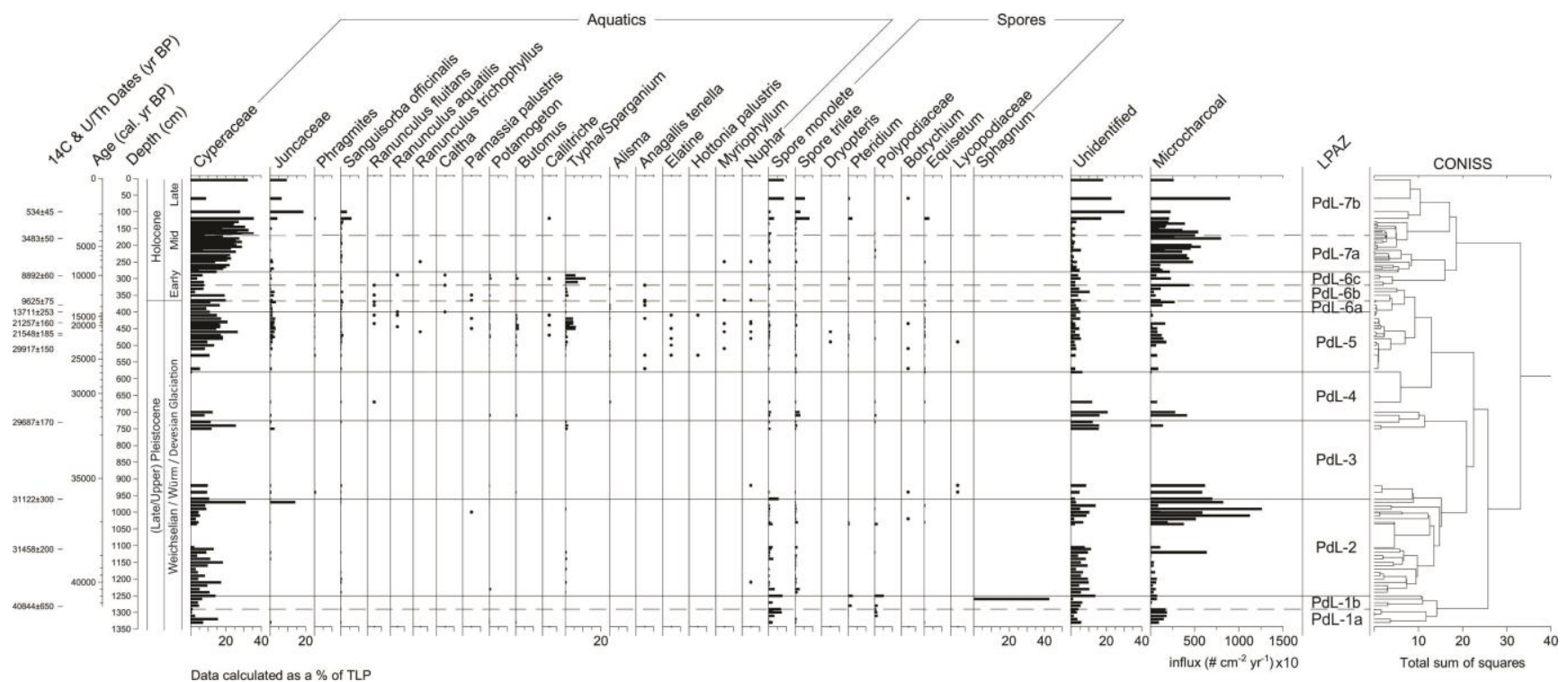

Fig.4d. Pollen diagram from Pian del Lago: aquatics, spores, microcharcoal

LPAZ PdL-1b (> 43,400-41,940 cal. BP; 1290-1250 cm) is characterized by the expansion of coniferous woodlands dominated by Abies (31\%) and Pinus (26\%), and a decline of mesophilous broadleaved woodlands recorded in PdL-1a (deciduous Quercus 8\%, Fagus 5.5\%). High presence of Poaceae (15\%) and Cyperaceae (4\%) indicate the persistence of grass-sedge swamp, fringed by Alnus (3\%), whilst the surprisingly high value of Sphagnum spores (43\%) suggests the deposition of moss-rich organic sediment. During this phase microcharcoal values are very low ( 200 fragments $\mathrm{cm}^{-2} \mathrm{yr}^{-1}$ ), indicating little influence of fire on ecosystem dynamics.

During LPAZ PdL-2 ( 41,940-35,470 cal. BP; 1250-960 cm), Pinus (including mugo/sylvestris) is dominant (69\%) together with Abies (7\% but with a peak $>40 \%)$, as well as a diverse mixture of woodland and shrubland species comprising Corylus (1\%), deciduous Quercus (0.7\%), Fagus (0.6\%), Castanea (0.6\%), Ulmus (0.5\%), Ericaceae (0.4\%) and Ephedra (0.3\%). Alnus (2.5\%) and Salix (1.3\%), together with Cyperaceae and Poaceae dominate the wetlands. Asteroideae, Caryophyllaceae, Plantago, Artemisia, Chenopodiaceae, Cichorioideae, Ranunculaceae, Apiaceae, Polygonaceae and Solidago are present. Microcharcoal values are low ( $\sim 300$ fragments $\left.\mathrm{cm}^{-2} \mathrm{yr}^{-1}\right)$ at the beginning and then increase, reaching a maximum value (>12,500 fragments $\left.\mathrm{cm}^{-2} \mathrm{yr}^{-1}\right)$ during 
the last part of this phase suggesting an important role of fire in shaping vegetation structure and composition.

During LPAZ PdL-3 ( 35,470-33,250 cal. BP; 960-725 cm) there is an overall reduction in Pinus ( 28\%) and Abies (7.5\%). Deciduous woodlands with Corylus (6.5\%), Alnus (between 35\% and 5\%), Quercus (2.6\%), Salix (2.5\%), Betula (1.7\%), Ulmus (0.6\%), Carpinus (0.45\%), Fagus $(0.35 \%)$ and Tilia $(0.30 \%)$ are present. The overall reduction in woodland cover is indicated by the increased proportion of shrubland (mainly Ericaceae, 4\%) and herbaceous (66\%) taxa. Poaceae (almost 30\%) significantly increase during the zone together with a diverse range of taxa including Caryophyllaceae, Ranunculaceae, Asteroideae, Artemisia and Cichorioideae. The wetland continues to be dominated by Cyperaceae (13\%), together with Typha $(0.5 \%)$. The zone has some samples with a very low pollen concentration $(<6000$ grains/gram) with poor pollen preservation, and therefore there are concerns over the reliability of these data. Microcharcoal values remain quite high but decrease with respect to the last part of the previous phase, with values $\sim 3400$ fragments $\mathrm{cm}^{-2} \mathrm{yr}^{-1}$.

LPAZ PdL-4 ( 33,250-26,880 cal. BP; $725-580 \mathrm{~cm})$ records an expansion of Pinus woodland (26\%, including Pinus mugo/sylvestris) with a diverse range of other woody taxa, including Alnus (6\%), Corylus (4\%), Carpinus (3\%), Abies (2.6\%), Salix (2.1\%), deciduous Quercus (1.7\%), Ulmus (1.6\%), Betula (1.5\%) and Fagus (1.1\%), as well as Ericaceae (4.6\%), Juniperus (1.4\%) and Buxus (1.1\%). Nevertheless, herbaceous taxa reach $57 \%$ of the pollen values and are dominated by Poaceae (27\%), as well as Chenopodiaceae (2\%), Cichorioideae (1.7\%), Apiaceae (1.4\%), Asteroideae (1\%) and Artemisia (1\%). Once again, the wetland is dominated by Cyperaceae (7\%). Microcharcoal influxes continue to decrease (values $~ 2500$ fragments $\mathrm{cm}^{-2} \mathrm{yr}^{-1}$ ). 
LPAZ PdL-5 ( 26,880-12,480 cal. BP; 580-400 cm) is characterized by the highest number of taxa (up to 55 TLP). Pinus (54\%, including Pinus mugo/sylvestris) remains dominant, together with Abies (5.7\%), Betula (1.9\%), Alnus (1.7\%), Picea (1.6\%), Fagus (1\%), Salix (0.7\%) and deciduous Quercus (0.7\%). Shrub taxa include Juniperus (0.5\%), Buxus (0.4\%) and Ephedra (0.23\%). Despite the formation of diatomite in the upper part of the zone, the woodland cover remains broadly similar throughout. Artemisia values are notably higher than in previous zones $(9 \%)$ and dominate the herbaceous layer together with Poaceae (11\%) and small amounts of Apiaceae (2\%), Chenopodiaceae (1.3\%) and Asteroideae (1.2\%). The wetland includes Cyperaceae, Juncaceae, Typha, Sanguisorba officinalis, Phragmites, Butomus, Myriophyllum, Equisetum and Callitriche. Microcharcoal values are characterised by a rapid decline during this phase $\left(\sim 600\right.$ fragments $\mathrm{cm}^{-2}$ $\left.\mathrm{yr}^{-1}\right)$.

During LPAZ PdL-6a ( 12,480-11,600 cal. BP; 400-367 cm) Pinus (56\%, including Pinus mugo/sylvestris) dominates, while Abies temporarily withdraws (2\%) and Picea (1\%) starts to decline. Deciduous woodlands are mainly composed of Salix (1\%), Alnus (0.8\%), Betula (0.4\%) and Fraxinus (0.35\%). Shrub taxa include Ephedra (0.4\%) and Juniperus $(0.3 \%)$. The herbaceous layer is dominated by Artemisia (14\%), together with Poaceae (9\%), Chenopodiaceae (4.5\%), Apiaceae (1.7\%) and Asteroideae (1.5\%). On the wetland, Cyperaceae (12\%) and Juncaceae (1.6\%) are the main taxa. Microcharcoal values $\left(\sim 1000\right.$ fragments $\left.\mathrm{cm}^{-2} \mathrm{yr}^{-1}\right)$ increase during this period with respect to the previous phase.

LPAZ PdL-6b ( 11,600-10,760 cal. BP; $367-330 \mathrm{~cm})$ is characterized by an increase in Abies $(5 \%)$ and deciduous Quercus (1\%), concomitant with the beginning of the Pinus decline (48\%, including Pinus mugo/sylvestris). Betula (3\%), Picea (0.4\%), Castanea (0.35\%), Fraxinus (0.3\%), and Juniperus $(1.5 \%)$ are also present. The most notable change in the herbaceous taxa is the decline in Artemisia (12\%), Chenopodiaceae (2\%) and Asteroideae (1.2\%), although there is still a diverse 
range of taxa including Poaceae (14\%), Plantago (1.3\%) and Apiaceae (1\%). The wetland includes Salix (1.4\%) and Alnus (1\%), with Cyperaceae (12\%), Juncaceae (1.5\%) and Typha (1\%). During this phase microcharcoal values $\left(\sim 800\right.$ fragments $\left.\mathrm{cm}^{-2} \mathrm{yr}^{-1}\right)$ are characterised by a decline.

LPAZ PdL-6c ( 10,760-9550 cal. BP; 330-280 cm) is dominated by Pinus (27\%, including Pinus mugo/sylvestris), Abies (22\%) and deciduous Quercus (6\%), together with Betula (5\%), Corylus (1.3\%), Fraxinus (1\%) and Tilia (0.9\%). Juniperus (0.8\%), Ephedra (0.65\%) and Buxus $(0.5 \%)$ also occur. The herbaceous layer is mainly composed of Poaceae (17\%), Artemisia (7.5\%), Chenopodiaceae (1.2\%) and Apiaceae (1.2\%). On the wetland, Alnus (1.4\%), Salix (0.4\%), Cyperaceae $(6.3 \%)$ and Typha $(6 \%)$ are present. Microcharcoal values $\left(\sim 1800\right.$ fragments $\left.\mathrm{cm}^{-2} \mathrm{yr}^{-1}\right)$ increase during this period with respect to the previous phase.

LPAZ PdL-7 ( 9550 cal. BP to the present day; 290-0 cm) spans the remaining part of the Holocene. Due to detailed previous research on this part of the sequence (Cruise et al., 2009), the pollen stratigraphical changes have simply been divided into two major sub-zones to aid description and brief discussion of the main vegetation changes: LPAZ PdL-7a ( 9550-3765 cal. BP) and 7b ( 3765-0 cal. BP).

LPAZ PdL-7a ( 9550-3205 cal. BP, 290-170 cm): Before 6000 cal. BP Abies $(24 \%)$ replaced Pinus (12\%) as the dominant tree, and deciduous Quercus (11\%), Corylus (6\%), Alnus (3\%), Betula (1.6\%), Ulmus (1.2\%), Ostrya (1.2\%) and Tilia (0.7\%) form a mixed temperate woodland, possibly with Quercus ilex (2.5\%) and Fagus (1.7\%), respectively at lower and higher altitudes. Vitis becomes more frequent. Ericaceae (2.4\%) spread and occupy dry and poor soils. Amongst the herbs, Poaceae significantly increase from this zone onwards makes up most of the herbaceous pollen, along with Cyperaceae. Artemisia has a clear and definitive decline resulting in a higher diversity of other herbaceous taxa typical of more mesic grasslands (e.g. Caryophyllaceae, 
Chenopodiaceae, Fabaceae, Apiaceae, Sanguisorba officinalis, Potentilla, Filipendula, Plantago,

Centaurea, Cirsium and Achillea). The increasing abundance of microcharcoal ( 2400 fragments $\mathrm{cm}^{-2} \mathrm{yr}^{-1}$ ) may suggest sustained human impact on the environment (see 5.2).

LPAZ PdL-7b ( 3205-0 cal BP, 170-0 cm): During this final part of the sequence Abies values drop (2.9\%) and Pinus continues to decrease (7\%). Fagus, Tilia and Carpinus almost disappear from the area (both $0.2 \%$ ). Despite a decline in deciduous Quercus (16.5\%), broadleaves dominate the landscape. The appearance of Castanea (2\%), Olea (1\%) and Juglans (0.4\%), which are important indicators of human activity throughout the Mediterranean, testifies their cultivation. Ericaceae remain abundant $(7 \%)$. After reaching minimum values, corresponding to a spread of woodland cover, Poaceae (26\%) increases again and, together with Cyperaceae (26\%), Juncaceae (3.5\%) and Sanguisorba officinalis (10\%) dominate the herbaceous layer, probably reflecting hydrological changes in the basin catchment. Cichorioideae, Plantago and Rumex show isolated peaks and, together with Cerealia, Caryophyllaceae and Centaurea, represent indicators of human activity

(Behre, 1981; Branch, 2004). The peak in fern spores together with an increase in microcharcoal $\left(\sim 3200\right.$ fragments $\left.\mathrm{cm}^{-2} \mathrm{yr}^{-1}\right)$ indicate an important role of fire in the vegetation succession, possibly due to periods of higher human activity. The abundance of unidentified pollen grains suggests caution in the interpretation of the upper part of the sequence.

\section{Discussion}

\subsection{Upper Late Pleistocene}

Our data from Pian del Lago indicate that the northern Apennines undoubtedly experienced periods of abrupt climatic and vegetation changes during the upper Late Pleistocene. The record is unique for this part of Italy and is one of the few terrestrial sedimentary deposits spanning the last glacial stage in southwestern Europe (see Allen and Huntley, 2000; Fletcher et al., 2010). It thus permits improved understanding of the spatial and temporal patterns of vegetation succession, and the 
possible causes of these changes. Although the radiocarbon dated pollen stratigraphy from Pian del Lago marshland does not have the geochronological precision of other central and southern Italian longer lake sequences, such as Lago Grande di Monticchio (Allen et al., 1999; Watts, 1985; Watts et al., 1996a,b) and Valle di Castiglione (Follieri et al., 1988), it does permit a broad correlation with these records, as well as with Mediterranean marine sequences (Cacho et al., 2001) and the Greenland ice core records (Rasmussen et al., 2014) (Fig. 5 and Fig. 6). Correlation with these sequences is dependent upon specific pinning points, most notably the termination of the Würm glacial stage at $\sim 14,300 \mathrm{cal}$. BP, the onset of the Holocene at $\sim 11,700$ cal. BP, and the expansion of pollen of woody taxa reflecting ameliorating climatic conditions (see Fletcher et al., 2010; Pini et al., 2010; Magri et al., 2015).

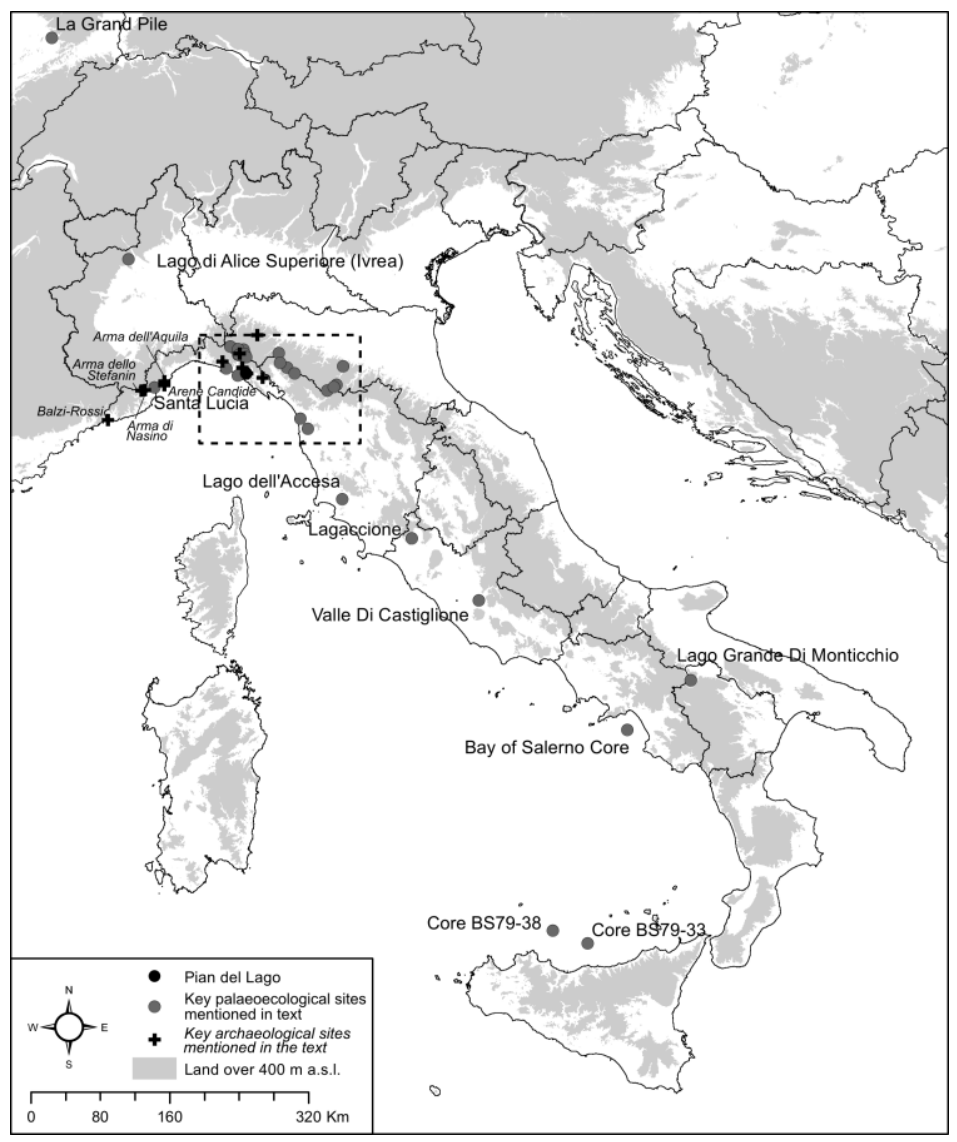

Fig. 5: Key Late Pleistocene and Holocene palaeoenvironmental and palaeoclimatic records from southwestern Europe mentioned in the text 


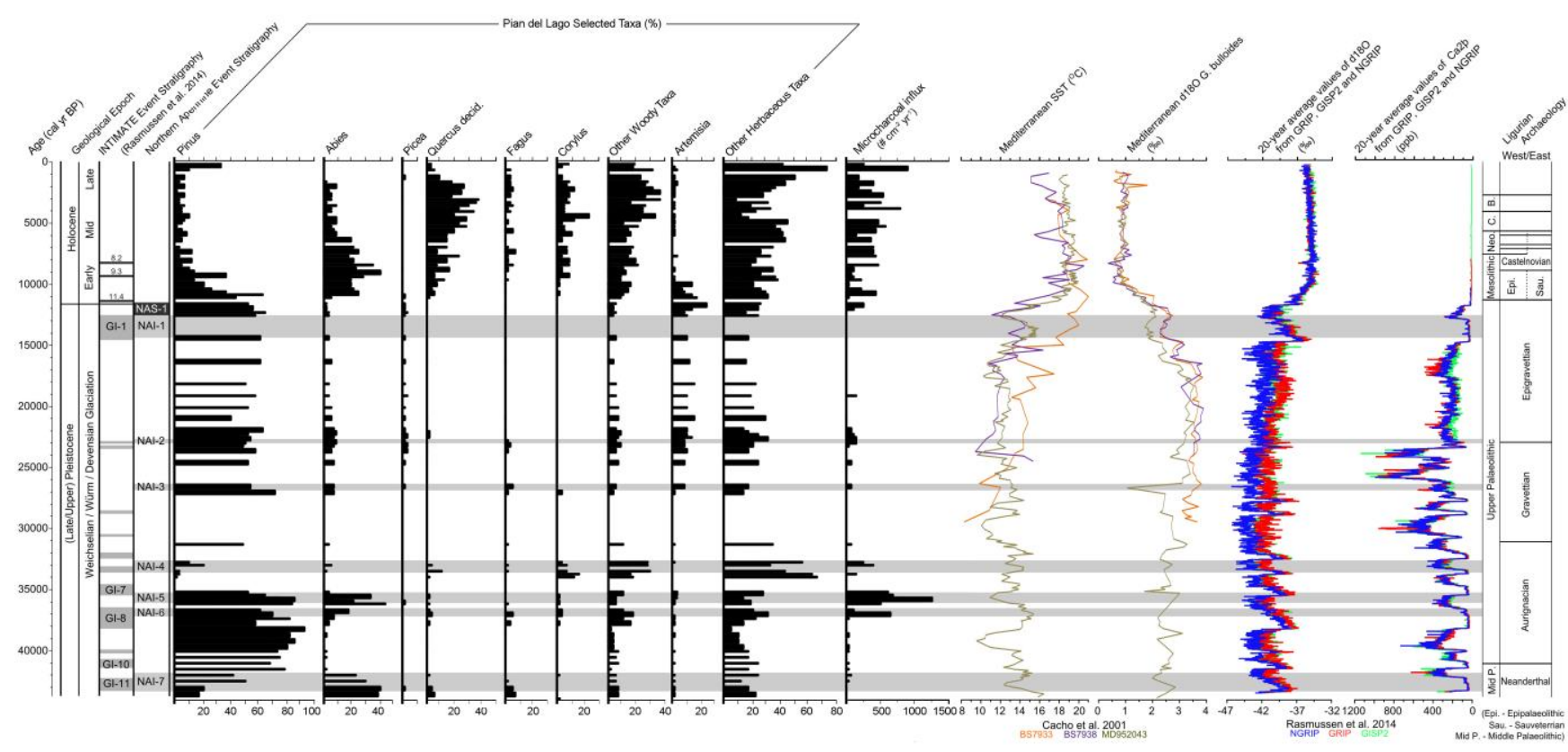

441

Figure 6: Selected taxa pollen diagram and event stratigraphy compared with the ice core and marine records, and INTIMATE event stratigraphy; grey bands indicate interstadial events identified in this research (in color online)

Several of the pollen-stratigraphical changes from Pian del Lago are interpreted here as vegetation responses to relatively mild climatic conditions (interstadial), in contrast to intervening colder climate phases (stadial). The biostratigraphical signature for the transition to interstadial conditions is highlighted by a seemingly 'abrupt' change to mesophilous woodland succeeded by the onset of cooler conditions indicated by a reduction in tree cover, poor pollen preservation and/or a major change in sedimentary deposition. Based on this assumption, we believe that they can be correlated with several of the well-recorded climatic fluctuations known as Dansgaard-Oeschger (D - O) events (Dansgaard et al., 1989; Rasmussen et al., 2014). Due to geochronological uncertainties and the poor pollen preservation of some parts of the sequence, the precise duration of each interstadial event at Pian del Lago is unclear, but it certainly appears that they varied considerably. Based on the ice core records for the $\mathrm{D}-\mathrm{O}$ events, it is also acknowledged that the same climatic event may not have occurred at precisely the same time in different regional scale archives due to transmission variability in oceanic and atmospheric D-O changes (Moreno et al., 2014). For this reason, and following published protocols (Rasmussen et al., 2014), we decided to label the events recorded at 
Pian del Lago as a Northern Apennine Interstadial (NAI) or a Northern Apennine Stadial (NAS)

461

462

463

464

465

with an associated number, and attempted a correlation with the Greenland ice core records (GI and

GS for interstadial and stadial, respectively), different Mediterranean marine sequences, and various central and southern Italian lake records (Table 4; Fig. 5 and Fig. 6; see Bosselin and Djindjian,

2002).

\begin{tabular}{|c|c|c|c|c|}
\hline $\begin{array}{l}\text { Pian del Lago local } \\
\text { pollen assemblage } \\
\text { zone (LPAZ) }\end{array}$ & $\begin{array}{l}\text { Event stratigraphy - } \\
\text { northern Apennines }\end{array}$ & $\begin{array}{l}\text { Lago Grande di } \\
\text { Monticchio } \\
\text { pollen zone } \\
\text { (Allen et al., } \\
\text { 2000) } \\
\end{array}$ & $\begin{array}{l}\text { Valle di } \\
\text { Castiglione } \\
\text { (Follieri et } \\
\text { al., 1988) }\end{array}$ & $\begin{array}{l}\text { INTIMATE event } \\
\text { stratigraphy (Rasmussen } \\
\text { et al., 2014) }\end{array}$ \\
\hline $\begin{array}{l}\text { PdL-6b } \\
\sim 11,600-10,760 \text { cal. } \\
\text { BP }\end{array}$ & Start of Holocene & $\begin{array}{l}1 \\
11,200- \\
\text { present }(11,200)\end{array}$ & Holocene & Start of Holocene \\
\hline $\begin{array}{l}\text { PdL-6a } \\
\sim 12,480-11,600 \text { cal. } \\
\text { BP }\end{array}$ & $\begin{array}{l}\text { NAS-1 } \\
\sim 12,480-11,560 \text { cal. } \\
\text { BP }\end{array}$ & $\begin{array}{l}2 \\
12,800-11,200 \\
(1600)\end{array}$ & $\begin{array}{l}\text { Younger } \\
\text { Dryas }\end{array}$ & $\begin{array}{l}\text { GS-1 12,896-11,703 a } \\
\text { b2k }\end{array}$ \\
\hline \multirow{3}{*}{$\begin{array}{l}\text { PdL-5 30,380- } \\
23,655 \text { to } 13,430- \\
11,310 \text { cal. BP } \\
(\sim 26,880-12,480 \text { cal. } \\
\text { BP) }\end{array}$} & $\begin{array}{l}\text { NAI-1 } \\
\sim 14,360-12,480 \text { cal. } \\
\text { BP }\end{array}$ & $\begin{array}{l}3 \\
14,300-12,800 \\
(1500)\end{array}$ & $\begin{array}{l}\text { Late Glacial } \\
\text { Interstadial }\end{array}$ & $\begin{array}{l}\text { Gl-1 (1a-1e) } \\
\sim 14,692-13,099 \text { a b2K }\end{array}$ \\
\hline & $\begin{array}{l}\text { NAI-2 } \\
\sim 23,030-22,800 \text { cal. } \\
\text { BP }\end{array}$ & $\begin{array}{l}4 \\
25,900-14,300 \\
(11,600) \\
\end{array}$ & Full Glacial & $\begin{array}{l}\text { GI-2.1 } \\
\sim 23,020-22,900 \text { a b2k }\end{array}$ \\
\hline & $\begin{array}{l}\text { NAI-3 } \\
\sim 26,880-26,400 \text { cal. } \\
\text { BP }\end{array}$ & $\begin{array}{l}5 a \\
29,400-25,900 \\
(3500) \\
\end{array}$ & $\begin{array}{l}\text { Lazio VI and } \\
\text { VII }\end{array}$ & No event \\
\hline $\begin{array}{l}\mathrm{PdL}-3 \sim 36,380- \\
34,630 \text { to } \sim 34,400- \\
31,080 \text { cal. BP } \\
(\sim 35,470-33,250 \text { cal. } \\
\text { BP) }\end{array}$ & $\begin{array}{l}\text { NAI-4 } \\
\sim 33,860-32,650 \text { cal. } \\
\text { BP }\end{array}$ & $\begin{array}{l}6 \\
34,900-31,800 \\
(3100)\end{array}$ & & $\begin{array}{l}\text { GI-6 }(\sim 33,740-33,360) \\
\text { and GI-5 } \\
\sim 32,500-32,040(5.2) \text { and } \\
\sim 30,840-30,600(5.1) \text { a } \\
\text { b2k }\end{array}$ \\
\hline \multirow[t]{2}{*}{$\begin{array}{l}\text { PdL-2 } \sim 44,740- \\
38,310 \text { to } \sim 36,380- \\
34,630 \text { cal. BP } \\
(\sim 41,950-35,470 \text { cal. } \\
\text { BP) }\end{array}$} & $\begin{array}{l}\text { NAI-5 } \\
\sim 36,050-35,160 \text { cal. } \\
\text { BP }\end{array}$ & $\begin{array}{l}7 \\
36,500-34,900 \\
(1600)\end{array}$ & Lazio IV & $\begin{array}{l}\text { GI-7 } \\
\sim 35,480-34,880 \text { a b2k }\end{array}$ \\
\hline & $\begin{array}{l}\text { NAI-6 } \\
\sim 37,130-36,650 \text { cal. } \\
\text { BP }\end{array}$ & $\begin{array}{l}8 \\
37,600-36,500 \\
(1100)\end{array}$ & & $\begin{array}{l}\text { GI-8 } \\
\sim 38,220-36,580 \text { a b2k }\end{array}$ \\
\hline $\begin{array}{l}\text { PdL-1b 45,230- } \\
41,070 \text { to } 44,740- \\
38,310 \text { cal. BP } \\
\text { ( 43,440-41,950 cal. } \\
\text { BP) }\end{array}$ & $\begin{array}{l}\text { NAI-7 } \\
\sim 43,440-41,950 \text { cal. } \\
\text { BP }\end{array}$ & $\begin{array}{l}11 \\
50,000-42,300 \\
(7700)\end{array}$ & Lazio II & $\begin{array}{l}\text { Gl-11 } \\
\sim 43,340-42,240 \text { a b2k }\end{array}$ \\
\hline
\end{tabular}


From $\sim 43,440-41,950$ cal. BP (NAI-7), the vegetation succession at Pian del Lago was characterized by the expansion of Abies and Pinus, as well as Fagus, Quercus (both deciduous and Q. ilex) and Picea. The predominance of these taxa also at Lago di Alice Superiore (Piedmont, northern Italy; Figure 5) suggests similar climatic conditions north of the Po Plain (Gianotti et al., 2015). At Valle di Castiglione (Lazio, central Italy; Figure 5), woodland mainly composed of Picea, Fagus, Ulmus and deciduous Quercus dominated during the Lazio II interstadial (Follieri et al., 1988, 1990, 1998). Similarly, at Lago Grande di Monticchio (Basilicata, southern Italy; Figure 5), the open woodland comprised Quercus, Fagus and Abies, with Tilia, Ulmus and Fraxinus (Allen et al., 2000). A marine record from the Bay of Salerno (Campania, southern Italy; Figure 5) similarly indicates this period favorable to meso-thermophilic vegetation (Russo Ermolli and Di Pasquale, 2002). The data from Pian del Lago are however quite different from several other southern European records that indicate a predominance of microtherm conifers (Pinus, Picea and Larix) or 480 just a few broadleaved trees (deciduous Quercus, Betula, Corylus) (e.g. Peyron et al., 1996; Willis et al., 2000; Woillard, 1978). Instead the dominance of mesophilous trees at Pian del Lago, which are similar or even higher to those recorded during the Late Holocene, clearly indicate a temperatehumid climate. The record also appears to confirm the existence of a temperature gradient between northern/central (cooler) and southern (warmer) Italy based upon the presence (or absence) of Picea 485 (see Allen et al., 2000; Beaudouin et al., 2005; Fletcher et al., 2010). According to Rasmussen et al. (2014), NAI-7 may be equated with Greenland Interstadial 11 (GI-11; 43,340-42,240 a b2K; Table

4). The timing also suggests a tentative correlation with the Hengelo Interstadial of north-western 489 Europe (Behre and van der Plicht, 1992; Helmens, 2013; Rasmussen et al., 2014; Vandenberghe 490 and van der Plicht, 2016). 
From $~ 37,130-36,650$ cal. BP (NAI-6), the vegetation cover at Pian del Lago was characterized by the presence of Corylus and Abies, as well as Pinus, Quercus, Alnus and Fagus, and may be equated with Greenland Interstadial 8 (GI-8, 38,220-36,860 a b2K; Table 4). There is no indication at Pian del Lago for the interstadial event evidenced during pollen zone 9 at Lago Grande di Monticchio and denoted by Lazio III at Valle di Castiglione (Follieri et al., 1998). Instead, NAI-6 chronologically correlates with zone 8 at Lago Grande di Monticchio (characterised by steppic vegetation dominated by Artemisia; Allen et al., 2000). As noted above, this difference in timing for the D-O event may be due to transmission variability between different parts of southwestern Europe or alternatively chronological uncertainties within the age models.

Between $~ 36,050$ and 35,160 cal. BP (NAI-5) the expansion of Abies, Pinus, and Artemisia at Pian di Lago indicates a further increase of wooded steppe vegetation, also recorded by Allen et al. (2000) at Lago Grande di Monticchio during pollen zone 7 (Betula, Quercus, Ulmus and Fagus), and by Follieri et al. (1998) during Lazio IV at Valle di Castiglione (deciduous Quercus, Corylus, Fagus, Tilia, Ulmus and Carpinus). Although the event appears to be chronologically correlated with the early stages of Greenland Interstadial 7 (GI-7, $\sim 35,480-34,880 \mathrm{~b} 2 \mathrm{~K}$ ), once again there is no clear sub-division of GI-7 based on the pollen data (GI-7a, b and c) (Table 4). The timing also suggests a tentative correlation with the Danekamp I Interstadial of north-western Europe (Behre and van der Plicht, 1992; Bosselin and Djindjian, 2002; Helmens, 2013; Rasmussen et al., 2014; Vandenberghe and van der Plicht, 2016).

During the period $\sim 33,860-32,650$ cal. BP (NAI-4) the vegetation succession at Pian di Lago was characterized by the expansion of Corylus, as well as Pinus and Quercus. Similarly, at Berceto (Emilia Romagna, northern Italy, Figure 1), the presence of Pinus and Picea forests support the occurrence of a warming event (Bertoldi et al., 2007). According to our findings, this may be equated with either Greenland Interstadial 6 or 5 (GI-6 and 5; 33,740-30,600 a b2K), or possibly 
517 both, with no clear stadial events (GS-6 and GS-5.2). However, this event appears to be 518 chronologically correlated with Lago Grande di Monticchio pollen zone 6 (Table 4), a stadial event 519 (Allen et al., 2000), which is anomalous. Tentatively, the event may be correlated with the 520 Danekamp II / Arcy Interstadial of north-western Europe (Behre and van der Plicht, 1992; Bosselin 521 and Djindjian, 2002).

523 From 35,470-33,250 cal. BP, the Pian di Lago pollen record is interrupted by the deposition of 524 Serpentinite, suggesting major erosion in the catchment area. The chronology indicates that this 525 event occurred between GI-7 and GI-6 and may reflect a deterioration in climate (stadial). Support 526 for this interpretation is provided by both the marine and ice core records, and it may be equated 527 with GS-7, a colder climatic event dated to $~ 34,740$ a b2K (Cacho et al., 2001; Rasmussen et al., 528 2014).

529

530 A second major erosional event indicated by the deposition of Serpentinite occurred at Pian del 531 Lago between $\sim 33,220$ and 26,880 cal. BP. Both the chronology and the comparison with marine 532 and ice core records suggest that this episode may be equated with Heinrich $3(\sim 30,000-29,000 \mathrm{cal}$. 533 BP) or GS-5.1 ( 30,600-28,900 a b2K), or possibly GS-4 ( 28,600-27,780 a b2K) and GS-3 534 ( 27,540-23,340 a b2K) (Guiot et al., 1993; Rashid and Grosjean, 2006; Rasmussen et al., 2014). 535 The increase in herbaceous taxa supports the existence of cooler conditions. The absence of clear 536 biostratigraphical evidence for GI-4 ( 28,900-28,600 a b2K) and GI-3 ( 27,780-27,540 a b2K) 537 during the zone is interesting, although the reason remains unknown (Rasmussen et al., 2014). In 538 contrast, at Berceto, pollen zone BER-4 has been tentatively correlated with the Tursac Interstadial 539 of north-western Europe, occurring sometime after 34,325-33,191 cal. BP (29,620 \pm 290 BP) and 540 characterised by the presence of Pinus and Picea forests (Bertoldi et al., 2007). 
During the period $\sim 26,880-26,400$ cal. BP (NAI-3) the vegetation cover at Pian del Lago is 543 dominated by Pinus with Abies, Betula, Picea, Fagus and deciduous Quercus. This diverse range of 544 taxa has been correlated with Lago Grande di Monticchio pollen zone 5a (Table 4; Allen et al., 545 2000). In agreement with the Pian del Lago sequence, this detailed record indicates an increase in woody taxa (especially Pinus), suggesting warmer conditions. Interestingly, this event cannot be linked with the ice core records (Rasmussen et al., 2014), but it does correlate with a major excursion in the $\delta 180$ marine record from the Mediterranean (Cacho et al., 2001) as well as with Lazio VI and VII Interstadials of central Italy (Follieri et al., 1998) (Figure 6). For this reason, NAI3 should be regarded as a highly significant climatic event in the northern Apennines that may require revision of the ice core event stratigraphy given the clear evidence in Figure 6 for climatic amelioration at this time (see Rasmussen et al., 2014).

At Pian del Lago, the presence of high pollen values of Artemisia, along with many other herbaceous taxa, between $\sim 26,400$ cal. BP ( 29,930-23,400 cal. BP) and $\sim 9970$ cal. BP ( 10,2709620 cal. BP) is of significance for several reasons:

(1) At $\sim 26,400$ cal. BP, it coincides with a sustained increase in Pinus and Abies. This persists until approximately $\sim 19,040$ cal. BP $(\sim 20,980-17,870$ cal. BP), when Abies declines and there is a temporary reduction in Pinus. This is also concurrent with the formation of diatomite at Pian del Lago. Thereafter, Pinus re-expands until $\sim 10,640$ cal. BP $(\sim 11,270-10,090$ cal. BP), when it is succeeded by Abies and Quercus. Throughout this period, the high presence of Artemisia indicates the existence of an open steppe woodland and shrubland cover, perhaps benefitting from climatic amelioration following the Last Glacial Maximum, which may have favoured soil development and the colonisation of a more diverse range of taxa. Our suggestion is supported by the ice core records, which arguably indicate a more sustained period of stable climatic conditions from 23,340 (GI-2.2) and 23,030 (GI-2.1) a b2K, and throughout Greenland Stadial 2.1 (GS-2.1), which spans the period 22,900-14,692 a b2K (Rasmussen et al., 2014). This overall trend is also reflected in the 
Mediterranean marine sequences (Cacho et al., 2001). GI-2.2/GI-2.1 has been correlated with the Laugerie Interstadial of north-western Europe $(\sim 23,500-22,000$ cal. BP), whilst at Berceto, Bertoldi et al. (2007) have tentatively linked the temporary expansion of Pinus and Picea at this time with the Lascaux Interstadial ( 21,000-20,000 cal. BP) (Behre and van der Plicht, 1992; Bosselin and Djindjian, 2002).

(2) The 'Younger Dryas' chronozone, a stadial event conventionally placed between 12,900 and 11,700 a b2k (GS-1 starts at $\sim 12,896$ a b2K in the ice core records; Rasmussen et al., 2014), has been recorded in a number of terrestrial and marine sequences in southwestern Europe, including the northern Apennines, and is characterised by the prevalence of a colder/drier climate (e.g. Lowe, 1992; Ponel and Lowe, 1992; Lowe and Watson, 1993; Lowe et al., 1994a, b; Watson, 1996; Cita et al., 1996; Watts et al., 1996a, b; Bertoldi et al., 2007; Vescovi et al., 2010a,b). The notable increase in Artemisia pollen values at Pian del Lago from $\sim 12,480-11,600$ cal. BP may be assigned to the 'Younger Dryas' (PdL-6a, NAS-1; Table 4). At Prato Spilla C (Emilia Romagna, northern Italy; Figure 5), the marked decline in Quercus and the expansion of a range of steppe herbs, including Artemisia, provides the clearest evidence for the event in the northern Apennines (Lowe, 1992), whilst it can be correlated with Lago Grande di Monticchio pollen zone 2 (Allen et al., 2000; de Beaulieu et al., 2017). The presence of an additional site in the northern Apennines with evidence for the 'Younger Dryas' stadial is an important confirmation of the widespread impact of this event in southwestern Europe.

(3) The persistence of Artemisia until $\sim 9970$ cal. BP is surprising, especially given the clear evidence for the expansion of those warmth loving taxa that characterise the early postglacial. This may reflect an ongoing landscape instability rather than a climate signal, which is supported by the continued deposition into the Pian del Lago basin of mineral-rich sediment rather than organic-rich sediments. 
593 Prior to the onset of GS-1, there are records in the northern Apennines for GI-1, a pronounced 594 interstadial lasting $\sim 1500$ years $(\sim 14,692-13,099$ b2K) documented in the ice core records 595 (Rasmussen et al., 2014; Table 4). Despite the evidence for a Pinus dominated woodland at the 596 beginning $(\sim 14,360 \mathrm{cal} \mathrm{BP})$ and at the end $(12,480 \mathrm{cal}$. BP $)$ of this phase, the presence of this event 597 at Pian del Lago is unclear. This may be attributed to either poor pollen preservation, or to a muted 598 response to a warmer period in this part of the northern Apennines. At Prato Spilla C (from $599 \sim 14,350$ cal BP), the Interstadial was characterised by the expansion of warm mixed forest 600 including Quercus, Tilia, Betula and Corylus (Lowe, 1992), whilst at Lago Grande di Monticchio 601 broadleaved deciduous forests with Quercus, Corylus, Fagus, Ulmus, Tilia and Alnus were present 602 (Allen et al., 2000).

603

604

\subsubsection{Palaeolithic Cultural History}

605 The upper Late Pleistocene vegetation history and event stratigraphy from Pian del Lago can be 606 correlated with main cultural changes occurred in the wider region, including the Maritime Alps (western Liguria) and the northern Apennines. PdL-1a (> 43,400 cal. BP) and PdL-1b (> 43,40041,940 cal. BP) can be equated with the late Middle Palaeolithic. Lithic tools (Neanderthal) attributed to the Middle Palaeolithic have been found near Pian del Lago, as well as other sites in the northern Apennines (e.g. Pianaccia di Suvero, Liguria; Ronco del Gatto, Emilia-Romagna). It is tempting to correlate NAI-7 ( 43,440-41,950 cal. BP) with a phase of late Neanderthal activity at Pian del Lago, although the lack of precisely dated, well-stratified archaeology makes this association uncertain.

During the Upper Palaeolithic ( 42,000-11,000 cal. BPPdL-2 to PdL-6a), the presence of six interstadials at Pian del Lago (NAI-6 to NAI-1) provides considerable potential for examining the relationships between human activity, climate variability and environmental change (see Kaniewski et al., 2005; Maggi, 2015). The Aurignacian ( 42,000-34,000 cal. BP in Italy; Mussi et al., 2006) 
has provided approximately 30 known sites in Italy, and only a small number of these are from the Maritime Alps and northern Apennines (e.g. Pian del Lago, Balzi Rossi sites, Ronco del Gatto; Mussi et al., 2006). The sequence at Mochi (Balzi Rossi), for example, has a stone tool assemblage indicating population movement between southern France, the Maritime Alps, northern Apennines and the Adriatic coast, and the exploitation of a range of animals. Several key radiocarbon dates spanning $\sim 41,500-37,500$ to $\sim 38,000-35,000$ cal. BP (level G) encompass both NAI-6 ( 37,13036,650 cal. BP) and NAI-5 ( 36,050-35,160 cal. BP). Whether occupation was facilitated by periods of warmer (interstadial) climate remains unclear due to chronological uncertainties. Nevertheless, the pollen data from Pian del Lago provide a valuable insight into the environment occupied by earliest European Modern Humans in this part of the northern Apennines.

During the Gravettian ( 34,000-20,000 cal. BP in Italy), lithic tools have once again discovered at Pian del Lago and Ronco del Gatto, as well as at the cave of Arene Candide in the Maritime Alps (Pettitt et al., 2015). The latter has provided stratified radiocarbon dates from charcoal and human remains, e.g. an age of $27,899-27,338$ cal. BP from a human femur (known as 'Il Principe') spanning GS-4 (starts $~ 28,600$ a b2k), GI-3 (starts $~ 27,780$ a b2k) and GS-3 (starts $~ 27,540$ a b2k) of the Greenland ice core event stratigraphy (Rasmussen et al., 2014). Whether the period of occupation is correlated with the ameliorating conditions of GI-3 is uncertain without further dating evidence. Therefore, once again the absence of enough well-stratified, precisely dated sites means that comparison with the event stratigraphy from Pian del Lago (NAI-4 33,860-32,650 cal. BP; NAI-3 26,880-26,400 cal. BP; NAI-2 23,030-22,800 cal. BP) is unfortunately problematic.

The Epigravettian cultural period ( 20,000-11,000 cal. BP in Italy) witnesses an important increase in evidence for human occupation in the Maritime Alps, but unfortunately there is little evidence from the northern Apennines. Charcoal records from cave sites (e.g. Arene Candide, Arma di Nasino, Arma dell' Aquila and Arma dello Stefanin; Barker et al., 1990) indicate the exploitation of 
regional vegetation composed of Abies and Pinus. During the Lateglacial Interstadial (NAI-1, 14,360-12,480 cal. BP, from Pian del Lago), charcoal data from Arma dello Stefanin and isotopic data from Arene Candide (Barker et al., 1990) suggest a significant climatic oscillation with an increase in mean annual temperature to $8-10{ }^{\circ} \mathrm{C}$, and the exploitation of more thermophilous vegetation, such as Quercus pubescens, Q. ilex, Corylus, Acer, Ulmus, Fagus, Alnus, Ostrya/Carpinus and Prunus. Arene Candide has also provided a unique insight into Epigravettian funerary practices, which are believed to represent a social response to harsh climatic conditions during the Younger Dryas stadial (NAS-1, 12,480-11,560 cal. BP, from Pian del Lago) (Sparacello et al., 2018). It is tempting to suggest therefore that the archaeological records indicate a response by human groups to late-glacial climatic variability both in terms of an adaptation to changing resource availability, and transformation of socio-cultural practices.

\subsection{Holocene}

The transition to the Early Holocene at Pian del Lago ( 11,600 cal. BP, PdL-6b) is marked by the progressive expansion of mesophilous woodland dominated by Abies and the decline of Pinus, probably P. mugo. Broadleaved woodland, such as deciduous Quercus, Alnus, Betula, Corylus and Fagus are still scarce, but are gradually starting to increase. This is consistent with previous work at Pian del Lago, which indicates the main expansion of Abies from 12,220-10,910 (start of Bg2) to 11,270-10,170 (start of Bg3) cal. BP (Cruise 1990a, 1990b; Cruise et al., 2009). At 9970 cal. BP $(290 \mathrm{~cm})$, there is unequivocal evidence for a major environmental change, which may be linked to ameliorating climatic conditions of the Early Holocene. This is marked by the formation of peat and a decline of Pinus and Artemisia, and a spread of broadleaved trees, namely deciduous Quercus, $Q$. ilex, Corylus, Alnus, Fagus, Ostrya, Tilia, Ulmus and Fraxinus, and mesophilous conifers (Abies) and heathland (Ericaceae). This is partly in agreement with the findings of Cruise et al. (2009) who record the main period of peat initiation shortly before 9550-9090 cal. BP (from $259 \mathrm{~cm}$ ) in core Barg94. However, the authors also record peat formation shortly after 12,220-10,910 cal. BP (from 
$396 \mathrm{~cm}$ ) in core Bg89. This indicates intra-site differences in the timing of the event, which may be attributed to sub-surface topographical variability and proximity of the core to the basin edge.

The sustained evidence for burning at Pian del Lago during the Early Holocene based on microcharcoal data could be due to human activity. During the Mesolithic ( 11,000-7800 cal. BP) the primary zone of human occupation was seemingly in the northern Apennines rather than the Maritime Alps (see 5.1). There is extensive indication of human activity (e.g. Pianaccia di Suvero, Passo della Camilla, Bosco delle Lame) characterised by rich artefactual assemblages, including scalene triangles, truncated and backed blades, bilateral backed points and microburins made from jasper and flint (Biagi and Maggi, 1984; Maggi, 1999; Maggi, Negrino, 2016). These sites suggest increasing exploitation at higher altitudes and principally around inter-montane basins. At Mogge di Ertola (Liguria), for example, sedimentological and pollen data suggest deforestation by burning during the Late Mesolithic (Cevasco et al., 2013). Alternatively, the increased fire frequency could be related to drier climatic conditions during the Early Holocene, and possibly periods of short-term climate change. There is no pollen evidence for the '9.3' climatic event ( $9350-9240$ a b2K, respectively) at Pian del Lago, although there is possible evidence for the '11.4' $(\sim 11,520-11,400$ b2K - Pre-Boreal Oscillation) and '8.2' ( 8300-8140 a b2K) events; the former is marked by high percentages of Artemisia pollen together with Pinus mugo, Juniperus and Betula (c.f. Di Rita et al., 2013, 2015; de Beaulieu et al., 2017), whilst the latter is marked by a temporary decline in Abies woodland, which is also recorded in other parts of the northern Apennines (Branch, 2013; Cruise et al., 2009; Lowe, 1992; Watson, 1996). During the earliest part of the Holocene ( 11,500-10,500 cal. BP) aridity has been used to explain the hiatus in sedimentation at several northern Apennines sites, while the expansion of Corylus and the temporary decline of Abies has been connected to higher summer temperatures and drought causing an increase in fire events (see Branch, 2013; Finsinger et al., 2006; Mercuri et al., 2011; Peyron et al., 2011). 
696 Cruise et al. (2009) suggested that fluctuating values of Abies and the presence of cereal pollen at 697 Pian del Lago between $\sim 8450-7880$ and $\sim 8050-7550$ cal. BP (start and end of Bg3b) were 698 associated with human activity (Early Neolithic). Throughout the Middle Holocene, Abies values 699 continued to vary whilst herbaceous and heathland taxa increased suggesting increasing human 700 impact on the environment. In addition to these previously published results, the present study also 701 underlines significant evidence for sustained burning activity in the area probably connected to the 702 use of agro-silvo-pastoral practices during the Neolithic, Copper Age and Bronze Age (see 703 Colombaroli et al., 2007, 2008; Tinner et al., 1999).

704

705 706 707 708 709

However, archaeological evidence for the Early Neolithic 'Impressa Ligure' Pottery Culture ( 7800-7000 cal. BP) and the Middle Neolithic Square Mouthed Pottery Culture ( 7000-6300 cal. BP) is mainly confined to the Maritime Alps (e.g. Barker et al., 1990; Biagi et al., 1987; Maggi, 1990; Rowley-Conwy, 1997). Indeed, the western part of Liguria has provided the earliest records of Neolithic occupation in North-Central Italy (e.g. Arene Candide cave). The evidence suggests movement of human communities over considerable distances, including parts of the northern Apennines, to exploit clay, flint and obsidian. Subsistence practices included the cultivation of Triticum spp., Hordeum spp., Lens culinaris and Vicia (Nisbet, 2006), and animal husbandry (Rowley-Conwy, 1997). Charcoal records indicate the exploitation of Quercus pubescens, Q. ilex, Acer, Fraxinus, Ulmus, Fagus, Pinus, Pistacia, Phillyrea, Olea, Taxus, Erica arborea and Arbutus unedo (e.g. Nisbet, 1997). By the Late Neolithic Chassey Culture ( 6300-5700 cal. BP), intensification of animal husbandry and cultivation had reduced the diversity of woodland taxa, especially deciduous trees, in the Maritime Alps and probably led to the formation of 'Mediterranean macchia' dominated by Quercus ilex, Arbutus unedo, Erica arborea, Rhamnus alaternus, Phillyrea, Olea and Pistacia lentiscus (Girod, 1997; Maggi and Nisbet, 1990; Nisbet, 1997). 
Despite the considerable lower number of known Neolithic archaeological sites in the northern Apennines compared to the Maritime Alps (e.g. Pianaccia di Suvero; Biagi et al., 1987; Maggi, 1983), palaeoecological results from several records (e.g. Braggio Morucchio et al., 1989; Cruise, 1990a, 1990b; Branch, 2002, 2004, Cruise et al., 2009) have provided consistent evidence for increasing human impact on the environment (e.g. burning activities, pastoralism, cultivation), supporting our results from Pian del Lago:

a) The vegetation succession from Abies and Corylus to deciduous Quercus, Q. ilex and Erica arborea together with the presence of cereal pollen during the Early Neolithic at Sestri Levante and Rapallo (<100 m asl) (Bellini et al., 2009b).

b) The temporary reduction in Abies woodland during the Late Mesolithic/Early Neolithic transition (from $~ 8100$ cal yrs BP) accompanied by evidence for burning, increase in herbaceous taxa and expansion of Fagus and Corylus woodland at Mogge di Ertola (1015 m asl) (Guido et al., 2013).

c) An increase in light loving taxa (i.e. Fraxinus and Ostrya), a slight reduction in Ulmus woodland, the expansion of Fagus woodland ( 6100 cal yrs BP) and the beginning of a sustained decline in Abies during the Middle Neolithic and early part of the Late Neolithic at Lago Riane (1279 m asl) (Branch, 2013).

d) The decline in Ulmus, Tilia and Fraxinus ( 7000 cal. BP), during the Middle Neolithic at Prato Spilla 'A' (Lowe et al., 1994a, 1994b).

e) The decline in Abies and expansion of Fagus from $~ 7000-5000$ cal. BP at Lago del Greppo (Vescovi et al. 2010a).

f) The decline of Abies at 6000 cal. BP at Pavullo and Lago di Massaciuccoli (Colombaroli et al., 2007; Mariotti-Lippi et al., 2007; Vescovi et al., 2010b).

From 3205 cal. BP (170 cm; PdL-7b) peat formation at Pian del Lago ends and is substituted by clay deposition and possible lowering of the summer water table, which resulted in poor pollen 
preservation. However, there is a clear anthropogenic signature in the palaeoecological record with an abundance of microcharcoal fragments indicating the use of burning activities in the area, a reduction in woodland taxa, the evidence for Castanea, Juglans, Olea and Vitis cultivations, as well as the presence of nitrophilous taxa (i.e. Chenopodiaceae, Plantago and Rumex) probably connected to grazing practices. These findings are consistent with those of Cruise et al. (2009) who also recorded a notable reduction in Abies and other tree taxa associated with burning. However, in contrast to the current study, these authors concluded that the charcoal evidence indicated "light, controlled burning" (p. 999) rather than woodland clearance by fire. In our opinion, this is unlikely given the significant rise in microcharcoal influx and the deposition of colluvium in the basin, suggesting a sustained period of landscape disturbance consistent with woodland clearance from the Late Bronze Age and Iron Age onwards.

This conclusion is consistent with the archaeological evidence, which clearly indicates that the pattern of human settlement and subsistence shifted from a dependence on the exploitation of lowland and coastal resources to a greater dependence on upland resources during the Copper Age ( 5800-4200 cal. BP) and Bronze Age ( 4200-2900 cal. BP). Sites are concentrated at altitudes between $400 \mathrm{~m}$ and $800 \mathrm{~m}$ asl (Bronze Age 'Castellari'), along watersheds and mountain hilltops (e.g. Uscio, northern Apennines) that are considered important strategic locations for access to mountain pastures (transhumant pastoralism), although artefactual remains have also been located at higher elevations. The period also witnesses the initiation of large-scale Copper Age mining (Maggi and Pearce, 2005, 2013), and the introduction of agricultural terracing during the Middle Bronze Age ( 3800 cal. BP; Maggi, 2004). As noted above, there were pronounced changes in the vegetation and environment during this period, and into the Iron Age and historic periods, which have been attributed to human activities including cultivation, animal husbandry and woodland management (e.g. Juglans, Castanea and Olea). The impact of climate change remains uncertain, but there is an increasing body of evidence to indicate that both human activities and vegetation 
succession were occasionally affected by abrupt events, e.g. 4200 cal. BP (Branch, 2013; Di Rita and Magri, 2019).

\section{Conclusions}

The palaeoenvironmental data presented here confirm the importance of Pian del Lago as a unique biostratigraphic archive for reconstructing the environmental history of the northern Apennines. In particular, the results of pollen analysis have made it possible to shed light on the upper Late Pleistocene and Early Holocene; periods poorly documented in this geographical area. The identification of seven interstadials from $\sim 43,000 \mathrm{cal}$. BP to the beginning of the Holocene is of considerable significance for our understanding of vegetation response in southwestern Europe to periods of abrupt climate change. Overall, the record indicates that for much of the upper Late Pleistocene, steppic taxa (mainly Artemisia and Chenopodiaceae) with shrubland of Juniperus, Salix and Ephedra, typical of central and northern Europe, were less prevalent in the northern Apennines. Tree species (e.g. Pinus, Abies and Alnus) apparently persisted throughout the period, although it should be noted that phases of poor pollen preservation (possibly equated with stadials) may have resulted in an expansion of steppic taxa. The presence of herbaceous taxa throughout the Pian del Lago sequence nevertheless indicates that the woodland was open in structure, supporting the hypothesis advocated for greater moisture stress during this period (cf. Allen and Huntley, 2000; Fletcher et al., 2010).

As noted, the chronological uncertainties associated with the Pian del Lago sequence preclude detailed discussion of the rate and duration of the main vegetation changes. The data from Lago Grande di Monticchio indicate, however, that vegetation succession during the upper Late Pleistocene was so rapid that it may have contributed to the magnitude of environmental variations in mountain ecosystems by affecting biogeochemical cycles (Fletcher et al., 2010). If this hypothesis is correct, it would be worth testing by undertaking further multi-proxy 
palaeoenvironmental and palaeoclimatic research at Pian del Lago (e.g. diatoms, Cladocera,

Chironomids) coupled with the development of a chronology of higher precision (e.g. radiocarbon dating, U-series dating and tephrochronology).

The persistence of Pinus, Picea and Larix along with mesophilous taxa (i.e. Abies, Quercus decid., Corylus and Alnus) during the Last Glacial Maximum (LGM) is noteworthy. According to Bertoldi et al. (2007), Picea was a typical species of interstadial periods in Emilia (eastern northern Apennines), whilst at Pian del Lago it sharply characterises the maximum expansion of the Würm glaciation, along with Larix. Today, relict formations of Picea near Passo del Cerreto ( $60 \mathrm{~km}$ from the study site) and Sestaione Valley ( 110 km away) can possibly be linked to its expansion in the northern Apennines (cf. Branch and Marini, 2013; Ravazzi, 2002). If regional pollen transportation is excluded, the site of Pian del Lago could therefore have been an intermediate area where Picea was present, linking the south-western Alps and the north-western Apennines. This part of the northern Apennines can therefore be regarded as a favourable environment for the persistence even during climatically unfavourable periods - of relatively demanding vegetation communities creating a refuge for mesophilous species, which then spread across southern Europe during the Early Holocene. Indeed there is now a growing body of palaeoenvironmental research in northern Italy and other parts of Europe indicating the presence of arboreal populations, especially conifers but also mesophilous taxa, during the climatically more hostile phases of the upper Late Pleistocene (e.g. Drescher-Schneider et al., 2007; Guiter et al., 2008; Jalut et al., 2010; Kaltenrieder et al., 2009; Miola et al., 2003; Müller et al., 2003; Willis and Van Andel, 2004; Willis et al., 2000).

Finally, this new investigation at Pian del Lago highlights the importance of using, whenever possible, heavy-duty percussion or rotary drilling equipment to explore basins (large and small) for palaeoenvironmental research. The equipment permitted the recovery of core samples to a much 
greater depth than the previous investigation (Cruise et al., 2009), which has provided a record of climate and environmental change that is unique to the northern Apennines.

\section{Acknowledgements}

The drilling campaign was carried out in 2005 in the frame of the Natura 2000 Network and within the EU LIFE Project "La storia dell'uomo e della natura", funded by the Ligurian Government, with a grant from EU for the regional enhancement (FESR) (misura 2.6b del Docup Ob.2 2000/2006) lead by M. G. Mariotti. This research did not receive any specific grant from funding agencies in the public, commercial, or not-for-profit sectors. For field and laboratory help, the authors wish to thank Drs. A. De Stefanis, P. De Stefanis, C. Parola, B.I. Menozzi and R. Maggi. The authors are grateful to two anonymous reviewers who with their suggestions contributed to improve the manuscript.

\section{References}

Alessio, M., Allegri, L., Bella, F., Calderoni, G., Cortesi, C., Dai Pra, G., De Rita, D., Esu, D., Follieri, M., Improta, S., Magri, D., Narcisi, B., Petrone, V., Sadori, L., 1986. 14 C dating, geochemical features, faunistic and pollen analyses of the uppermost $10 \mathrm{~m}$ core from Valle di Castiglione (Rome, Italy). Geologica Romana, 25, 287-308 (issued 1989).

Allen, J.R.M., Brandt, U., Brauer, A., Hubbertens, H.W., Huntley, B., Keller, J., Kraml, M., Mackensen, A., Mingram, J., Negendank, J.F.W., Nowaczyk, N.R., Oberhänsli, H., Watts, W.A., Wulf, S., Zolitschka, B., 1999. Rapid environmental changes in southern Europe during the last glacial period. Nature 400, 740-743. 
858 Allen, J.R.M., Huntley, B., 2000. Weichselian palynological records from southern Europe:

859 correlation and chronology. Quaternary International 73/74, 111-125.

860

Allen, J.R.M., Watts, W.A., Huntley, B., 2000. Weichselian palynostratigraphy palaeovegetation 862 and palaeoenvironment: the record from Lago Grande di Monticchio, Southern Italy. Quaternary 863 International 73/74, 91-110.

864

Arobba, D., Calderoni, G., Caramiello, R., Carraro, F., Giardino, M., Quagliolo P., 1997.

Palynological and radiometric evidence of a last glacial-interstadial from peat sediments in the 867 Ivrea morainic amphiteatre (NW-Italy). Geologia Insubrica 2(2), 143-148.

868

Arobba, D., Caramiello, R., Firpo, M., Mercalli, L., Morandi, L., Rossi, S., 2018. New evidence on the earliest human presence in the urban area of Genoa (Liguria, Italy): A multi-proxy study of a mid-Holocene deposit at the mouth of the Bisagno river. The Holocene 28, 1918-1935.

Barker, G., Biagi, P., Clark, G., Maggi, R., Nisbet, R. 1990. From hunting to herding in the Val 874 Pennavaira (Liguria - Northern Italy), in: Biagi, P., (Ed.), The Neolithisation of the Alpine Region. Museo Civico Di Scienze Naturali, Brescia, pp. 99-121. 
881 Behre, K.-E., 1981. The interpretation of anthropogenic indicators in pollen diagrams. Pollen et 882 Spores 23, 225-245.

883

884

Behre, K.-E., van der Plicht, J., 1992. Towards an absolute chronology for the last glacial period in 885 886

Europe: radiocarbon dates from Oerel, northern Germany. Vegetation History and Archaeobotany $1,111-117$.

887

888

Bellini C., Cevasco R., Moreno D., Guido M.A., Montanari C., 2009a. Mogge di Ertola, Aveto 889 valley, Ligurian Apennines: Evidence of past cultural landscapes, in: Krzywinski, K., O’Connell, 890 891 M., Kuster, H. (Eds.), Cultural Landscapes of Europe, Fields of Demeter, Haunts of Pan. Aschenbeck Media, Bremen, pp. 108-109.

892

Bellini, C., Mariotti Lippi, M., Montanari, C., 2009b. The Holocene landscape history of the NW 894 Italian coasts. The Holocene 19(8), 1161-1172.

895 896

Bertoldi, R., Chelli, A., Roma, R., Tellini, C., 2007. New data from Northern Apennines (Italy) pollen sequences spanning the last 30,000 yrs. Il Quaternario, Italian Journal of Quaternary 898 Sciences 20(1), 3-20.

899

Biagi, P., Maggi, R., 1984. Aspects of the Mesolithic age in Liguria. Preistoria Alpina 19, 159-168.

Biagi, P., Maggi, R., Nibet, R., 1987. Excavations at Arma dello Stefanin (Val Pennavaira 903 Albenga, northern Italy) 1982-1986. Mesolithic Miscellany 8, 10-11.

904

Blaauw, M., Christen, J.A., 2011. Flexible paleoclimate age-depth models using an autoregressive gamma process. Bayesian Analysis 6 (3), 457-474. 
Bosselin, B., Djindjian, F., 2002. Un essai de reconstitution du climat entre 40000 BP et 10000 BP 909 à partir des séquences polliniques de tourbières et de carottes océaniques et glaciaires à haute résolution. Archeologia e Calcolatori, 13, 275-300.

Braggio Morucchio, G., Guido, M.A., Montanari, C., 1989. Profilo palinologico e storia della vegetazione. In Gentile, S., Guido, M.A., Montanari, C., Paola, G., Braggio Morucchio, G., Petrillo,

M., Ricerche geobotaniche e saggi di cartografia della vegetazione del piccolo bacino di Lago Riane (Liguria). Braun-Blanquetia (1988) 3, 17-20.

Branch, N., 2002. L'analisi palinologica per lo studio della vegetazione e della sua gestione. In:

Campana, N. and Maggi, R. (eds.) Archeologia in valle Lagorara. Istituto Italiano Di Preistoria e Protostoria, Florence, pp. 339-353.

Branch, N.P., 2004. Late Wurm Lateglacial and Holocene environmental history of the Ligurian Apennines, Italy, in: Balzaretti, R., Pearce, M., Watkins, S. (Eds.), Ligurian Landscapes: Studies in Archaeology, Geography and History. Accordia Research Institute, University of London, London, 315-334.

Branch, N.P., Marini, N.A.F., 2013. Mid-late Holocene environmental change and human activities in the northern Apennines, Italy. Quaternary International 353, 34-51. 
933 Branch, N.P., Morandi, L., 2015. Late Würm and Early-Middle Holocene environmental change 934 and human activities in the Northern Apennines, Italy. Il Capitale Culturale 12, 537-563.

935

936 Branch, N.P., Black, S., Maggi, R., Marini, N.A.F., 2014. The Neolithisation of Liguria (NW Italy): 937 An environmental archaeological and palaeoenvironmental perspective. Environmental 938 Archaeology 19, 196-213.

939

940 Cacho, I., Grinalt, J.O., Canals, M., Sbaffi, L., Shackleton, N.J., Schönfeld, J., Zahn, R., 2001. 941 Variability of the western Mediterranean Sea surface temperatura during the last 25,000 years and 942 its connection with the Northern Hemisphere climatic changes. Paleooceanography and 943 Paleoclimatology 16, 40-52.

944

945 Cevasco, A., De Pascale, A., Guido, M. A., Montanari, C., Maggi, R., Nicosia, C., 2013. Le Mogge 946 di Ertola (Appennino ligure): uncontributo all'archeologia del fuoco e all'archeologia dell'acqua, 947 in: Cevasco, R. (Ed.), La natura della montagna. Scritti in ricordo di Giuseppina Poggi. Oltre 948 Edizioni, Sestri Levante, pp. 413-427.

949

950 Christen, J.A., Pérez, S., 2009. A new robust statistical model for radiocarbon data. Radiocarbon $951 \quad 51,1047-1059$.

952

953 Cita, M.B., De Lange, G., Sala, M.C., Osio, A., Mariani, A.R., Marotta, P.A., 1996. The record of 954 the last glaciation in two deep-sea cores from the Sicily Channel of Capo Rossello (Central 955 Mediterranean). Il Quaternario 9, 493-498.

956 
957 Colombaroli, D., Marchetto, A., Tinner, W., 2007. Long-term interactions between Mediterranean 958 climate, vegetation and fire regime at Lago di Massaciuccoli (Tuscany, Italy). Journal of Ecology 959 95, 755-770. https://doi.org/10.1111/j.1365-2745.2007.01240.x

960

961 Colombaroli, D., Vannière, B., Emmanuel, C., Magny, M., Tinner, W., 2008. Fire-vegetation 962 interactions during the Mesolithic-Neolithic transition at Lago dell'Accesa, Tuscany, Italy. The 963 Holocene 18, 679-92.

964

965 Cruise, G.M., 1990a. Holocene peat initiation in the Ligurian Apennines, northern Italy. Review of 966 Palaeobotany and Palynology 63, 173-182.

967

968 Cruise, G.M., 1990b. Pollen stratigraphy of two Holocene peat sites in the Ligurian Apennines, 969 northern Italy. Review of Palaeobotany and Palynology 63, 299-313.

970

971 Cruise, G.M., Maggi R., 2000. Pian del Lago (Bargone), paesaggio costruito e paesaggio naturale 972 tra la fine della glaciazione ed il medioevo, in: Figone, F., Franceschini, I., Stagnaro, A. (Eds.), 973 Museo Parma Gemma, vent'anni di attività culturali e di ricerche. Comunità Montana Val 974 Petronio, Recco, pp. 10-13.

975

976 Cruise, G.M., Macphail, R.I., Linderholm, J., Maggi, R., Marshall P.D., 2009. Lago di Bargone, 977 Liguria, N Italy: A reconstruction of Holocene environmental and land-use history. The Holocene 978 19(7), 987-1003.

979

980 Dansgaard, W., White, J.W.C., Johnsen, S.J., 1989. The abrupt termination of the Younger Dryas 981 climate event. Nature 339, 532-534. 
983 de Beaulieu, J.-L., Brugiapaglia, E., Joannin, S., Guiter, F., Zanchetta, G., Wulf, S., Peyron, O., 984 Bernardo, L., Didier, J., Stock, A., Rius, D., Magny, M., 2017. Lateglacial-Holocene abrupt 985 vegetation changes at Lago Trifoglietti in Calabria, Southern Italy: the setting of ecosystems in a 986 refugial zone. Quaternary Science Reviews, 158, 44-57. http://10.1016/j.quascirev.2016.12.013. 987 hal-01662646

988 Di Rita, F., Anzidei, A.P., Magri, D., 2013. A Lateglacial and early Holocene pollen record from 989 Valle di Castiglione (Rome): Vegetation dynamics and climate implications. Quaternary 990 International, 288, 73-80.

991

992 Di Rita, F., Magri, D., 2019. The 4.2 ka event in the vegetation record of the central Mediterranean. 993 Climate of the Past 15, 237-251.

995 Drescher-Schneider R., de Beaulieu J.-L., Magny M., Walter-Simonnet A.-V., Bossuet G., Millet 996 L., Brugiapaglia E., Drescher A., 2007. Vegetation history, climate and human impact over the last 997 15,000 years at Lago dell'Accesa (Tuscany, Central Italy). Vegetation History and Archaeobotany 998 16, 279-299. http://doi: 10.1007/s00334-006-0089-z.

1000 Faccini, F., Piccazzo, M., Robbiano, A., 2009. A deep-seated gravitational slope deformation in the 1001 upper Bargonasco Valley (Ligurian Apennines). Geografia Fisica e Dinamica Quaternaria 32, 73 100282.

1004 Finsinger, W., Tinner, W., van der Knapp, W.O., Ammann, B., 2006. The expansion of hazel 1005 (Corylus avellana L.) in the southern Alps: a key for understanding its early Holocene history in 1006 Europe? Quaternary Science Reviews 25, 612-631. 
1008 Fletcher, W. J., Sánchez Goñi, M.F., Allen, J. R.M., Cheddadi, R., Combourieu-Nebout N., 1009 Huntley, B., Lawson I., Londeix, L., Magri D., Margari,V., Müller, U. C., Naughton, F., Novenko 1010 E., Roucoux K., Tzedakis P.C., 2010. Millennial-scale variability during the last glacial in 1011 vegetation records from Europe. Quaternary Science Reviews, 29, (21-22), 2839-2864.

1013 Follieri, M., Magri, D., Sadori, L., 1988. 250.000 year pollen record from Valle di Castiglione 1014 (Roma). Pollen et Spores 30, 329-356.

1016 Follieri, M., Magri, D., Sadori, L., 1990. Pollen stratigraphical synthesis from Valle di Castiglione 1017 (Roma). Quaternary International (1989) 3-4, 81-84.

1019 Follieri, M., Giardini, M., Magri D., Sadori, L.,1998. Palynostratigraphy of the last glacial period 1020 in the volcanic region of central Italy. Quaternary International, 47-48, 3-20.

Gianotti, F., Forno, M.G., Ivy-Ochs, S., Kubik, P.W., 2008. New chronological and stratigraphical 1023 data on the Ivrea amphitheatre (Piedmont, NW Italy). Quaternary International 190, 123-135.

1025 Gianotti, F., Forno, M.G., Ivy-Ochs, S., Monegato, G., Pini, R., Ravazzi, C., 2015. Stratigraphy of 1026 the Ivrea morainic amphitheatre (Italy): an updated synthesis. Alpine and Mediterranean 1027 Quaternary $28(1), 29-58$.

1029 Girod, A., 1997. Arene Candide: Holocene land snails, in: Maggi, R. (Ed.), Arene Candide: a 1030 Functional and Environmental Assessment of the Holocene Sequence. Il Calamo, Roma, pp. 1251031136. 
1033 Grimm, E.C., 1987. CONISS: A FORTRAN 77 program for stratigraphically constrained cluster analysis by the method of incremental sum of squares. Computers and Geosciences 13, 13-25.

Grimm, E.C., 1993. TILIA Version 2.0.b.4 (software). Illinois State Museum, Springfield.

Guido, M.A., Menozzi, B.I., Montanari, C., Scipioni, S., 2003. Il sito di 'Mogge di Ertola' come 1039 potenziale fonte per la storia ambientale del crinale Trebbia-Aveto. Archeologia Postmedievale 6, $1040 \quad 111-116$.

Guido, M.A., Mariotti Lippi, M., Menozzi, B.I., Placereani, S., Montanari, C., 2004a. Il paesaggio 1043 vegetale montano della Liguria centro-occidentale nell'Età del Ferro: area del Monte Beigua 1044 (Savona), in: De Marinis, R.C., Spadea, G. (Eds.), I LIGURI. Un antico popolo europeo tra Alpi e 1045 Mediterraneo, SKIRA, Ginevra-Milano, pp. 91-95.

Guido, M.A., Mariotti Lippi, M., Menozzi, B.I., Placereani, S., Montanari, C., 2004b. Ambienti 1048 costieri nella Riviera ligure di Levante tra le Età dl Bronzo e del Ferro: aree di Rapallo e di 1049 Chiavari, in: De Marinis, R.C., Spadea, G. (Eds.), I LIGURI. Un antico popolo europeo tra Alpi e 1050 Mediterraneo, SKIRA, Ginevra-Milano, pp. 78-81.

Guido, M.A., Mariotti Lippi, M., Menozzi, B.I., Placereani, S., Montanari, C., 2004c. Il paesaggio 1053 vegetale della costa toscana settentrionale negli ultimi tre millenni a.C., in: De Marinis, R.C., 1054 Spadea, G. (Eds.), I LIGURI. Un antico popolo europeo tra Alpi e Mediterraneo, SKIRA, Ginevra1055 Milano, pp. 84- 85.

Guido, M., Molinari, C., Montanari, C., 2009. Primi dati palinologici per la storia ambientale 1058 tardo-pleistocenica della Liguria orientale, in Di Marzio, P., Fortini, P., Scippa, G.S. (Eds.), Le 
1059 scienze botaniche nella cultura e sviluppo economico del territorio. Atti $104^{\circ}$ Congresso della 1060 Società Botanica Italiana, Campobasso, 16-19 settembre 2009, 272.

1061

1062 Guido, M. A., Menozzi, B. I., Bellini, C., Placereani, S. and Montanari, C. 2013. A palynological 1063 contribution to the environmental archaeology of a Mediterranean mountain wetland (NW 1064 Apennines, Italy). The Holocene 23, 1517-27.

1065

1066 Guiot, J., Harrison, S., Prentice, I.C., 1993. Reconstruction of Holocene Precipitation Patterns in 1067 Europe Using Pollen and Lake-Level Data. Quaternary Research 40(2), 139-149.

1069 Guiter, F., Andrieu-Ponel, V., de Beaulieu, J.-J., Nicoud, G., Ponel, P., Blavoux, B., Gandouin, E., 1070 2008. Palynostratigraphy of some Pleistocene deposits in the Western Alps: A review. Quaternary 1071 International 190, 10-25.

Helmens, K.F., 2013. The Last Interglacial-Glacial cycle (MIS 5-2) re-examined based on long proxy records from central and northern Europe. Technical Report TR-13-02, Svensk

1075 Kärnbränslehantering AB Swedish Nuclear Fuel and Waste Management Co, 1-59.

1077 Ivanovich, M., Harmon, R. S. (Eds.), 1992. Uranium Series Disequilibrium Applications to 1078 Environmental Problems. Oxford University Press, Oxford.

1080 Jalut, G., Turu Michels, V., Dedoubat, J-J., Otto, T., Ezquerra, J., Fontugne, M., Belet, J.M., 1081 Bonnet, L., García de Celis, A., Redondo-Vega, J.M., Vidal-Romaní, J.R., Santos, L., 2010. 1082 Palaeoenvironmental studies in NW Iberia (Cantabrian range): Vegetation history and synthetic 
approach of the last deglaciation phases in the western Mediterranean. Palaeogeography, 1084 Palaeoclimatology, Palaeoecology 297, 330-350.

Kaltenrieder, P., Belis, C.A., Hofstetter, S., Ammann, B., Ravazzi, C., Tinner, W., 2009.

Environmental and climatic conditions at a potential Glacial refugial site of tree species near the

Southern Alpine glaciers. New insights from multiproxy sedimentary studies at Lago della Costa 1089

(Euganean Hills, Northeastern Italy). Quaternary Science Reviews 28, 2647-2662.

1090

Kaniewski, D., Renault-Miskowsky, J., Tozzi, C., Lumley, H. De., 200. Upper Pleistocene and Late

Holocene vegetation belts in western Liguria: an archaeopalynological approach. Quaternary 1093 International 135, 47-63.

Lowe, J.J., 1992. Pollen stratigraphy and radiocarbon dating of late-glacial and early Holocene lake sediments from the northern Apennines, Italy. Boreas 21, 319-334.

Lowe, J.J. and Watson, C., 1993. Lateglacial and early Holocene pollen stratigraphy of the northern Apennines, Italy. Quaternary Science Reviews 12, 727-738.

Lowe, J.J., Branch, N., Watson, C., 1994a. The chronology of human disturbance of the vegetation of the northern Apennines during the Holocene, in Highland zone exploitation in southern Europe, 1103 edited by Biagi P., Nandris J., Brescia: Museo Civico Di Scienze Naturali, pp. 171-189. 
1108 Ludwig, K.R., 2008. Isoplot User's Manual. Berkeley Geochronology Center, Special Publication 1109 No. 4, pp. 76.

1111 Ludwig, K.R., Paces J.B., 2002. Uranium-series dating of pedogenic silica and carbonate, Crater 1112 Flat, Nevada. Geochimica et Cosmochimica Acta 66, 487-506.

1114 Maggi, R., 1983. Il Neolitico, pp 45-58, in Maggi, R. (Ed.), Preistoria nella Liguria Orientale. 1115 Recco. Siri.

1117 Maggi, R. (Ed.), 1990. Archeologia dell'Appennino Ligure gli scavi del Castellaro di Uscio: un 1118 insediamento di crinale occupato dal Neolitico alla conquista Romana. Collezione di Monografie 1119 Preistoriche ed Archeologiche 8.

Maggi, R., 1999. Coasts and uplands in Liguria and Northern Tuscany from the Mesolithic to the 1122 Bronze Age, in: Tykot, R.H., Morter, J., Robb, J.E. (Eds.), Social Dynamics of the Prehistoric 1123 Central Mediterranean. Accordia Research Institute, London, 47-65.

1125 Maggi, R., 2000. Aspetti di archeologia del territorio in Liguria: la formazione del paesaggio dal 1126 Neolitico all'Età del Bronzo. Annali Istituto ‘Alcide Cervi’ 19, 143-162.

1128 Maggi, R., 2004. I monti sun eggi: the making of the Ligurian landscape in prehistory, in: 1129 Balzaretti, R., Pearce, M., Watkins, C. (Eds.), Ligurian Landscapes, Studies in Archaeology, 1130 Geography and History. Accordia Research Institute, University of London, London, pp. 71-82. 
1132 Maggi, R., 2015. I monti sono vecchi. Archeologia del paesaggio dal Turchino alla Magra. De 1133 Ferrari., Genova.

1134

1135 Maggi, R., Nisbet, R., 1990 . Prehistoric pastoralism in Liguria. Rivista di Studi Liguri LVI (1-4), $1136 \quad 265-296$.

1138 Maggi, R., Pearce, M., 2005. Mid fourth-millennium copper mining in Liguria, north-west Italy: the 1139 earliest known copper mines in Western Europe. Antiquity 79, 66-77.

1141 Maggi, R., Pearce, M., 2013. Cronologia mineraria in Liguria, in Cocchi, D. (Ed.), Cronologia 1142 assoluta e relativa dell'Età del Rame in Italia. QuiEdit, Verona, pp. 5-15.

1144 Maggi, R., Negrino, F., 2016. The paradoxical pattern of the Mesolithic evidence in Liguria: 1145 piecing together the puzzle. Preistoria Alpina 48, 133-138.

1147 Magri, D., 2010. Persistence of tree taxa in Europe and Quaternary climate changes. Quaternary 1148 International $219(1-2), 145-151$.

1150 Magri, D., Agrillo, E., Di Rita, F., Furlanetto, G., Pini, R., Ravazzi, C., Spada, F., 2015. Holocene 1151 dynamics of tree taxa populations in Italy. Review of Palaeobotany and Palynology 218, 267-284.

1153 Mariotti Lippi, M., Guido, M.A., Menozzi, B.I., Trinci, C., Montanari, C., 2004. The late 1154 Pleistocene-Holocene evolution of the coastal plain of the Ligurian Sea (Tuscany and Liguria, 1155 Italy) by means of palynological analysis. POLEN 14, 525-526 
1157 Mariotti Lippi, M., Guido, M.A., Menozzi, B. Bellini, C., Montanari, C., 2007. The Massaciuccoli 1158 Holocene pollen sequence and the vegetation history of the coastal plains by the Mar Ligure 1159 (Tuscany and Liguria, Italy). Vegetation History and Archaeobotany 16, 267-277.

1161 Menozzi, B.I., Fichera, A., Guido, M.A., Mariotti Lippi, M., Montanari, C., Zanchetta, G., 1162 Bonadonna, F.P., Garbari, F., 2002. Lineamenti Paleoambientali del bacino del Lago di 1163 Massaciuccoli (Toscana Nord-Occidentale, Italia). Atti Soc. tosc. Sci. nat., Mem., Serie B, 109, 1164 177-187.

Mercuri , A.M., Sadori, L., Uzquiano Ollero, P., 2011. Mediterranean and north-African cultural 1167 adaptations to mid-Holocene environmental and climatic changes . The Holocene 21(1), 189-206. 1168 https://doi.org/10.1177/0959683610377532

1170 Miola, A., Albanese, D., Valentini, G., Corani, L., 2003. Pollen data for a biostratigraphy of LGM 1171 in the venetian Po Plain. Il Quaternario, Italian Journal Quaternary Sciences 16, 21-25.

1173 Montanari, C., Guido, M.A., Cornara, L., Placereani, S., 1998. Tracce polliniche di boschi neolitici 1174 di abete bianco in Val Bisagno (area urbana di Genova). Biogeographia XIX, 133-143.

Montanari, C., Bellini, C., Guido, M.A., Mariotti Lippi, M., 2014. Storia dell'ambiente costiero del 1177 Mar Ligure sulla base di analisi biostratigrafiche. Studi costieri 22, 209-223.

1179 Moore, P.D., Webb, J.A., Collinson, M.E., 1991. Pollen Analysis. Blackwell Scientific 1180 Publications, London. 
1182 Morandi, L.F., Branch, N.P., 2018. Long-range versus short-range prehistoric pastoralism. 1183 Potential of palaeoecological proxies and a new record from western Emilia, northern Apennines, 1184 Italy, in: Pelisiak, A., Nowak, M., Astaloş, C. (Eds.), People and the Mountains. Archaeopress 1185 Publishing Ltd, Stroud, pp. 47-60.

Moreno, A., Svensson, A., Brooks, S., Connor, S., Engels, S., Fletcher, W., Genty, D., Heiri, O., 1188 Labuhn, I., Perşoiu, A., Peyron, O., Sadori, L., Valero-Garcés, B., Wulf, S., Zanchetta, G. and data contributors, 2014. A compilation of Western European terrestrial records 60-8 ka BP: towards an understanding of latitudinal climatic gradients. Quaternary Science Reviews 106, 167-185.

Müller, U.C., Pross, J., and Bibus, E., 2003. Vegetation response to rapid climate change in central

Europe during the last 140,000 yr based on evidence from the Füramoos pollen record. Quaternary Research 59, 235-245. http://doi: 10.1016/S0033-5894(03)00005-X.

Mussi, M., Gioia, P., Negrino, F., 2006. Ten small sites: the diversity of the Italian Aurignacian, in:

Bar-Yosef, O., Zilhão, J. (Eds.), Towards a definition for the Aurignacian. Proceedings of the Symposium held in Lisbon, Portugal, June 25-30, 2002. Instituto Português de Arqueologia, Lisbon, 189-210.

Neymark, L.A. and Paces, J.B., 2000. Consequences of slow growth for 230Th/U dating of 1203

1204 Neymark, L.A., Paces, J.A., 2013. Ion-probe U-Pb dating of authigenic and detrital opal from 1205 Neogene-Quaternary alluvium. Earth and Planetary Science Letters 361, 98-109. 
1207 Neymark, L.A., Amelin, Y.V., Paces, J.B., 2000. 206Pb-230Th- 234U-238U and 207Pb-235U 1208 geochronology of Quaternary opal, Yucca Mountain, Nevada. Geochimica et Cosmochimica Acta $120964,2913-2928$.

1210

1211 Neymark, L.A., Amelin, Y., Paces, J.B., Peterman, Z.E., 2002. U-Pb ages of secondary silica at 1212 Yucca Mountain, Nevada: implications for the paleohydrology of the unsaturated zone. Applied 1213 Geochemistry 17, 709-734.

1214

1215 Nisbet, R., 1997. Arene Candide: charcoal remains and prehistoric woodland use, in: Maggi, R. 1216 (Ed.), Arene Candide: a Functional and Environmental Assessment of the Holocene Sequence. Il 1217 Calamo, Roma, pp. 103-112.

1219 Nisbet, R. 2006. Agricoltura del Neolitico Antico alle Arene Candide (Savona), in: Cucuzza, N., 1220 Medri, M. (Eds.), Archeologie, Studi in onore di Tiziano Mannoni. Edipuglia, Bari, pp. 331-335.

1222 Pettitt, P., Richards, M., Maggi, R., Formicola, V., 2015. The Gravettian burial known as the 1223 Prince ("Il Principe”): new evidence for his age and diet. Antiquity 77, 15-19.

1225 Peyron, O., Guiot, J., Cheddadi, R., Tarasov, P., Reille, M., de Beaulieu, J.-J., Bottema, S., Andrieu, 1226 V., 1996. Climatic reconstruction in Europe for 18,000 yr B.P. from pollen data. Quaternary 1227 Research 49, 183-196. 
1229 Peyron, O., Goring, S., Dormoy, I., 2011. Holocene seasonality changes in the central

1230 Mediterranean region reconstructed from the pollen sequences of Lake Accesa (Italy) and Tenaghi

1231 Philippon (Greece). The Holocene 21(1), 131-146. https://doi.org/10.1177/2F0959683610384162

1233 Piccazzo, M., Firpo, M., Ivaldi, R., Arobba, D., 1994. Il delta del fiume Centa (Liguria 1234 occidentale): un esempio di modificazione recente del clima e del paesaggio. Il Quaternario, Italian 1235 Journal of Quaternary Sciences 7(1), 293-298.

1236

1237 Pini, R., Ravazzi, C., Reimer P.J., 2010. The vegetation and climate history of the last glacial cycle 1238 in a new pollen record from Lake Fimon (southern Alpine foreland, N-Italy). Quaternary Science 1239 Reviews, 29 (23-24), 3115-3137.

1240

1241 Ponel, P., Lowe, J.J., 1992. Coleopteran, pollen and radiocarbon evidence from the Prato Spilla 'D' 1242 succession, N, Italy. Comptes Rendus de I'Acadèmie de Sciences, Paris, Serie II, 615, 1425-1431.

1244 Punt, W. (Ed.), 1976. The Northwest European Pollen Flora I. Elsevier Science Publishers, 1245 Amsterdam.

1247 Punt, W., Blackmore, S. (Eds.), 1991. The Northwest European Pollen Flora VI. Elsevier Science 1248 Publishers, Amsterdam.

1250 Punt, W., Clarke, G.C.S. (Eds.), 1980. The Northwest European Pollen Flora II. Elsevier Science 1251 Publishers, Amsterdam.

1253 Punt, W., Clarke, G.C.S. (Eds.), 1981. The Northwest European Pollen Flora III. Elsevier Science 1254 Publishers, Amsterdam. 
1256 Punt, W., Clarke, G.C.S. (Eds.), 1984. The Northwest European Pollen Flora IV. Elsevier Science 1257 Publishers, Amsterdam.

1259 Punt, W., Blackmore, S., Clarke, G.C.S. (Eds.), 1988. The Northwest European Pollen Flora V. 1260 Elsevier Science Publishers, Amsterdam.

1262 Punt, W., Blackmore, S., Hoen, P.P. (Eds.), 1995. The Northwest European Pollen Flora VII. 1263 Elsevier, Amsterdam.

1265 Rashid, H. and Grosjean, E., 2006. Detecting the source of Heinrich layers: An organic 1266 geochemical study. Paleoceanography 21, 1-20.

1268 Rasmussen, S.O., Bigler, M., Blockley, S.P., Blunier, T., Buchardt, S.L., Clausen, H.B., Cvijanovic, 1269 I., Dorthe Dahl-Jensen, D., Johnsen, S.J., Fischer, H., Gkinis, V., Guillevic, M., Hoek, W.Z., Lowe, 1270 J.J., Joel, B. Pedro, Popp, T., Seierstad, I.K., Steffensen, J.P., Svensson, A.M., Vallelonga, P., 1271 Vinther, B.M., Walker, M.J.C., Wheatley, J.J. and Winstrup, M., 2014. A stratigraphic framework 1272 for abrupt climatic changes during the LastGlacial period based on three synchronized Greenland 1273 ice-core records: refining and extending the INTIMATE event stratigraphy. Quaternary Science 1274 Reviews 106, 14-28.

1276 Ravazzi, C., 2002. Late Quaternary history of spruce in southern Europe. Review Palaeobotany 1277 and Palynology 120, 131-177.

1279 Reille, M., 1992-1998. Pollen et spores d'Europe et d'Afrique du Nord. Laboratoire de botanique 1280 historique et palynology, Marseille. 
1282 R Core Team, 2016. R: A Language and Environment for Statistical Computing. R Foundation for 1283 Statistical Computing, Austria, Vienna.

1285 Reimer, P.J., Bard, E., Bayliss, A., Beck, J.W., Blackwell, P.G., Bronk Ramsey, C., Caitlin E Buck, 1286 C.E., Cheng, H., Edwards, R., Friedrich, M., Grootes, P.M., Guilderson, T.P., Haflidason, H., 1287 Hajdas, I., Hatté, C., Heaton, T.J., Hoffmann, D.L., Hogg, A.G., Hughen, K.A., Kaiser, K.F., 1288 Kromer, B., Manning, S.W., Niu, M., Reimer, R.W., Richards, D.A., Scott, E.M., Southon, J.R., 1289 Staff, R.A., Turney, C.S.M., van der Plicht, J. 2013. IntCal13 and Marine13 Radiocarbon Age 1290 Calibration Curves 0-50,000 Years Cal BP. Radiocarbon 55(4), 1869-1887.

Rowley-Conwy, P. 1997. The animal bones from Arene Candide (Holocene sequence): final report, 1293 in Maggi, R. (Ed.), Arene Candide: a Functional and Environmental Assessment of the Holocene Sequence. Il Calamo, Roma, pp. 153-279.

Russo Ermolli, E. and Di Pasquale, G., 2002. Vegetation dynamics of south-western Italy in the last Archaeobotany 11 (3), 211-220.

Sparacello, V.S., Rossi, S., Pettitt, P., Roberts, C., Riel-Salvatore, J., Formicola, V., 2018. New insights on Final Epigravettian funerary behavior at Arene Candide Cave (Western Liguria, Italy). Journal of Anthropological Sciences 96, 1-24.

Sprynskyy, M., Kovalchuka, I., Buszewski, B., 2010. The separation of uranium ions by natural and modified diatomite from aqueous solution. Journal of Hazardous Materials 181 (1-3), 700-707. 
1307 Stuiver, M., Polach, H., 1977. Discussion: Reporting of 14C Data. Radiocarbon 19, 355-363.

1309 Stuiver, M., Kra, R. (Eds.), 1986. Calibration Issue. Radiocarbon 28(2B), 805-1030.

1311 Tinner, W., Hubschmid, P., Wehrli, M., Ammann, B., Conedera, M., 1999. Long-term forest fire 1312 ecology and dynamics in southern Switzerland. Journal of Ecology 87, 273-89.

1314 Vandenberghe, J. and van der Plicht, J., 2016. The age of the Hengelo interstadial revisited, 1315 Quaternary Geochronology 32, 21-28.

Vermeesch, P., 2018. IsoplotR: a free and open toolbox for geochronology. Geoscience Frontiers 9, 1318 1479-1493.

Vescovi, E., Ammann, B., Ravazzi, C., 2010a. A new Late-glacial and Holocene record of 1321 vegetation history from Lago del Greppo, northern Apennines, Italy. Vegetation History and 1322 Archaeobotany 19, 219-233.

1324 Vescovi, E., Petra Kaltenrieder, P., Tinner, W., 2010b. Late-Glacial and Holocene vegetation 1325 history of Pavullo nel Frignano (Northern Apennines, Italy). Review of Palaeobotany and 1326 Palynology 160, 32-45.

1328 Watson, C.S. 1996. The vegetational history of the northern Apennines, Italy: Information from 1329 three new sequences and a review of regional vegetational change. Journal of Biogeography 23, $1330 \quad 805-841$. 
1332 Watts, W.A., 1985. A long pollen record from Laghi di Monticchio, southern Italy: a preliminary 1333 account. Journal of the Geological Society of London 142, 491-499.

1335 Watts, W.A., Allen, J.R.M., Huntley, B. and Fritz, S.C., 1996a. Vegetation history and climate of 1336 the last 15,000 years at Laghi di Monticchio, southern Italy. Quaternary Science Reviews 15, 113 1337132.

1339 Watts, W.A., Allen, J.R.M. and Huntley, B., 1996b. Vegetation history and palaeoclimate of the 1340 last glacial period at Lago Grande di Monticchio, southern Italy. Quaternary Science Reviews 15, $1341 \quad 133-154$

Willis, K.J., Rudner, E., Sümegi, P., 2000. The Full-Glacial Forests of Central and Southeastern 1344 Europe. Quaternary Research 53, 203-213.

Willis, K.J., van Andel T.H., 2004. Trees or no trees? The environments of central and eastern 1347 Europe during the Last Glaciation. Quaternary Science Reviews 23, 2369-2387.

1349 Woillard, M.G., 1978. Grande Pile peat bog: a continuous pollen record for the last 140.000 years. 1350 Quaternary Research 9, 1-21.

1352 Yokoyama, Y., Nguyen, H-V., 1980. Direct and non-destructive dating of marine sediments, 1353 manganese nodules, and corals by high resolution gamma-ray spectrometry, in Saruhashi, K. (Ed.), 1354 Isotope Marine Chemistry. Uchida-Rokaku, Tokyo, pp. 235-265. 
1359 LIST OF FIGURES and captions

1360 Figure 1: Location of Pian del Lago and key Late Pleistocene and Holocene palaeoenvironmental records from the northern Apennines mentioned in the text

Figure 2: Photographs of Pian del Lago during the field investigations (top - west facing; bottom east facing)

Figure 3: Lithostratigraphy, and age-depth model of Pian del Lago, Northern Apennines, Italy

Figure 4: Pollen diagram from Pian del Lago, Northern Apennines, Italy

Figure 5: Key Late Pleistocene and Holocene palaeoenvironmental and palaeoclimatic records from southwestern Europe mentioned in the text

Figure 6: Selected taxa pollen diagram and event stratigraphy compared with the ice core and marine records, and INTIMATE event stratigraphy; grey bands indicate interstadial events identified in this research

1378 Table 1: Results of the radiocarbon and U-series dating

1379 Table 2: Proportions (\%) of minerals present in samples analysed for U-Series dating

1380 Table 3: Simplified lithostratigraphy for Pian del Lago (core S1)

1381 Table 4: Event stratigraphy for the Northern Apennines 